\title{
Nucleotide host markers in the influenza A viruses
}

\section{Wei Hu}

Department of Computer Science, Houghton College, Houghton, USA.

Email:wei.hu@houghton.edu

Received 7 May 2010; revised 23 May 2010; accepted 25 May 2010.

\begin{abstract}
In the efforts to understand the molecular characteristics responsible for the ability of influenza viruses to cross species, various amino acid host markers in influenza viruses were uncovered. Our previous study identified a collection of novel amino acid host markers in ten proteins of 2009 pandemic H1N1. As an extension of our prior work, the objective of the current study was to employ Random Forests, a robust pattern recognition technique, to discover nucleotide host makers in the ten corresponding genes of 2009 pandemic H1N1, along with those in the genes of avian and swine viruses. Although different, there was an association between the amino acid markers in proteins and the nucleotide markers in the related genes due to codon translations. Moreover, nucleotide host markers have the capability to indicate important positions within a codon for host switches as well as the significance of synonymous mutations on host shifts, all of which amino acid markers could not provide. Our findings highlighted that two or even three nucleotide markers could coexist within a single codon, and the different importance values of these markers could further discriminate the multiple markers within a codon. The nucleotide markers found in this study rendered a comprehensive genomic view of the complex and systemic nature of host adaptation. They verified and enriched the known amino acid markers and offered a larger set of finer host markers for further experimental confirmation.
\end{abstract}

Keywords: 2009 Pandemic H1N1; Host Switch Marker; Influenza; Mutation; Random Forests

\section{INTRODUCTION}

The swine-origin 2009 pandemic H1N1 was a clear reminder that understanding the biological mechanisms of cross-species transmission of influenza viruses remained an urgent and crucial research topic. Extensive search of host-shift markers in the influenza viruses resulted in a rich set of avian-human or swine-human markers [1-7]. However, sequence analysis of the recently emerged 2009 pandemic H1N1 virus suggested the absence of these well-known host switch markers [8]. Although the symptoms of 2009 pandemic H1N1 were mild, the fear was that the new virus might mutate to a more virulent virus. A recent experiment [9] indicated that the introduction of traditional virulence markers (mutations) in PB2 of 2009 pandemic H1N1 did not confer increased virulence or transmission, implying that these markers had minimum impact on this new virus.

To tackle the question of where to find the host markers in 2009 pandemic H1N1, it was hypothesized in [8] that they might exist outside of the space of the previously discovered markers. A new procedure using Random Forests was designed to identify a collection of novel amino acid host markers in ten proteins of 2009 pandemic H1N1, which included, in addition to the SR polymorphism found in [10], a set of markers in PB2 that might play compensatory roles in efficient replication and transmission of this novel virus. The purpose of this study was to uncover nucleotide host markers in the ten corresponding genes of 2009 pandemic H1N1 to provide finer and complement information about the host adaptation of this new virus. Furthermore, the nucleotide host markers in the ten corresponding genes of avian and swine viruses were also included in this report.

Using nucleotide sequences, it was found in $[11,12]$ that mononucleotide composition, rather than the higherorder compositions, was sufficient to distinguish the human and avian viruses with high accuracy. The viruses that replicated in mammals including 2009 pandemic $\mathrm{H} 1 \mathrm{~N} 1$ were more likely to change $\mathrm{G}$ to $\mathrm{A}$ in the mRNA than vice versa. The patterns of nucleotide frequency according to host species demonstrated that the 2009 pandemic H1N1 virus had been evolving in swine prior to its emergence. Another separate report [13] confirmed that the pattern of nucleotide composition of HA and NA genes of 2009 pandemic H1N1 was closest to that of swine H1N1 compared with the viruses of other 
origins and this novel virus originated from swine H1N1 based on the codon usage bias. To study the selective pressure acting on each gene segment of 2009 pandemic H1N1 [14], the ratio between the rate of non synonymous substitutions per non synonymous site and the rate of synonymous substitutions per synonymous sites was computed, exhibiting an active purifying selection on all segments. Specially, purifying selection was extreme on NP, MP, PA and PB1, moderate on NS and HA. PB1-F2 protein is a virulence factor in influenza viruses. However, genomic annotations of 2009 pandemic H1N1 [15] discovered a nucleotide mutation $(\mathrm{C} \rightarrow \mathrm{A})$ to render a stop codon at position 12 , which resulted in a truncated PB1-F2 protein for this new virus.

Many host markers are amino acid markers including the ones in [8]. However, amino acids and nucleotides are related because of codon translations. Some codon substitutions are more likely than others due to the genetic code structure and selective pressures favor some codons for enhanced translation speed and fidelity. Therefore, it is not realistic to assume that each amino acid is equally likely to be encoded by any of its codons. In general codon-based host shift information is more accurate than the amino acid-based. Based on this observation, the current study aimed to identify nucleotide host markers through a large-scale comparative analysis of ten genes of influenza viruses. These markers could demonstrate which positions within a codon were important and uncover the synonymous mutations that might be crucial for host switches. To facilitate the discovery of these markers, this report proposed to employ Random Forests, a robust pattern recognition technique that was previously applied successfully as a cost effective approach to the study of ten proteins of influenza viruses in [8].

\section{MATERIALS AND METHODS}

\subsection{Sequence Data}

All influenza virus nucleotide sequences corresponding to the protein sequences used in [8] were retrieved from the Influenza Virus Resource (http://www.ncbi/nlm.nih.giv/ genomes/FLU/FLU.html) of the National Center for Biotechnology Information (NCBI). All the sequences used in the study were aligned with MAFFT [16].

\subsection{Random Forests}

Random Forest, proposed by Leo Breiman in 1999 [17], is an ensemble classifier based on many decision trees. Each tree is built on a bootstrap sample from the original training set and is unpruned to obtain low-bias trees. The variables used for splitting the tree nodes are a random subset of the whole variable set. The classification decision of a new instance is made by majority voting over all trees. About one-third of the instances are left of the bootstrap sample and not used in the construction of the tree. These instances in the training set are called "outof-bag" instances and are used to evaluate the performance of the classifier, which can achieve both low bias and low variance with bagging and randomization.

\subsection{Feature Selection Using Random Forests}

Random Forest calculates several measures of variable importance. The mean decrease in accuracy measure was employed in [18] to rank the importance of the features in prediction. This measure is based on the decrease of classification accuracy when values of a variable in a node of a tree are permuted randomly. In this study, two packages of R, randomForest and varSelRF [18], were utilized to compute the importance of the nucleotides in a given gene sequence dataset. The effectiveness and robustness of this technique as a feature selection method has been demonstrated in various studies [19-24].

Random Forests produce non-deterministic outcomes. To compensate this bias, the Random Forests algorithm was run multiple times and then the average of the results was taken. The importance of each position in the nucleotide sequences was based on the averaged calculations by using the function randomVarImpsRF in varSelRF repeated 5 times.

\section{RESULTS}

\subsection{Comparison of Ten Genes of Influenza Viruses Based on their Consensus Nucleotide Sequences}

To explore the relationship among the genes of influenza viruses, the Hamming distance, defined as the number of positions at which the corresponding nucleotides of two sequences are different, of any two consensus nucleotide sequences of avian, human, 2009 pandemic H1N1, and swine viruses was calculated. The distance information in Table 1 provided insight into the sequence similarity between the genes of different viruses. In particular, the distances between 2009 pandemic H1N1 and avian, human, and swine viruses reflected the origin of 2009 pandemic $\mathrm{H} 1 \mathrm{~N} 1$ with its genes derived from avian (PB2 and PA), human H3N2 (PB1), classical swine (HA, NP, and NS), and Eurasian avian-like swine H1N1 (NA and M) lineages [25].

\subsection{Important Nucleotide Host Markers in Ten Genes of Influenza Viruses}

In [8], important amino acid host markers in ten proteins of influenza viruses were uncovered, based on which the novel host markers in 2009 pandemic H1N1 were identified. The main task here was to find the nucleotide host markers in the ten corresponding genes of 2009 pan- 
Table 1. This table contains the Hamming distances of ten genes of avian, human, 2009 pandemic H1N1, and swine viruses based on their consensus nucleotide sequences.

\begin{tabular}{ccccccccccc}
\hline Genes & HA & NA & NP & M1 & M2 & NS1 & NS2 & PA & PB1 & PB2 \\
\hline Dist (Avian, 2009_pandemic) & 389 & 249 & 242 & 51 & 15 & 108 & 40 & 160 & 256 & 231 \\
Dist (Human, 2009_pandemic) & 389 & 298 & 250 & 98 & 35 & 115 & 55 & 352 & 118 & 354 \\
Dist (Swine, 2009_pandemic) & 135 & 263 & 78 & 83 & 15 & 47 & 19 & 192 & 184 & 211 \\
Dist (Avian, Human) & 390 & 339 & 254 & 79 & 28 & 61 & 40 & 332 & 215 & 329 \\
Dist (Avian, Swine) & 337 & 316 & 212 & 64 & 12 & 77 & 28 & 161 & 158 & 177 \\
Dist (Human, Swine) & 342 & 244 & 222 & 64 & 30 & 89 & 42 & 269 & 152 & 286 \\
\hline
\end{tabular}

demic H1N1, avian, and swine viruses, thus offering further information about the adaptation of these viruses to humans. In the following sections, each of the ten genes of human viruses was compared to that of 2009 pandemic H1N1, avian, and swine viruses. Random Forests were employed to locate the top 20 important codons, served as host markers, in the genes of influenza that could separate human from 2009 pandemic H1N1, avian, and swine viruses. In different genes there were several codons that contained two or even three important nucleotide markers selected by Random Forests, a remarkable feature that amino acid markers lack.

The top important codons in each gene for differentiating human from 2009 pandemic H1N1, avian, and swine viruses were displayed in single figure (Figures 1-10). The comparison of amino acid markers in [8] and nucleotide markers found in this study revealed several shared sites in each protein/gene, illustrating their significance as host markers. The consensus nucleotides (codons) comprising these sites in each gene were presented in Tables 2-11, which could also serve as a confirmation and refinement of the results in [8].

Due to high genetic variation of the HA and NA genes, only the HA nucleotide sequences of $\mathrm{H} 1$ subtype and the NA nucleotide sequences of N1 subtype of 2009 pandemic H1N1, avian, human, and swine viruses were utilized in the current analysis. Therefore, the important codons in HA and NA found in this study were subtype-specific. Because all the PB1-F2 proteins of 2009 pandemic H1N1 were truncated and nonfunctional, the genes encoding these proteins were excluded in this study.

\subsubsection{HA Gene}

One of the advantages of the nucleotide markers over amino acid markers is their ability to represent the synonymous mutations that might be significant for host shifts. In comparison of human with avian, 2009 pandemic H1N1, and swine viruses, there were several sy- nonymous mutation positions in HA with high importance. They were 197(3) $(\mathrm{cac}(\mathrm{H})$, $\operatorname{cat}(\mathrm{H}))$ and $230(3)$ (gag(E), gaa(E)) in avian and 197(3) $(\operatorname{cac}(\mathrm{H}), \operatorname{cat}(\mathrm{H}))$ and 254(3) $(\operatorname{gga}(\mathrm{G}), \operatorname{ggg}(\mathrm{G}))$ in 2009 pandemic H1N1. Codon 197(3) had a very high importance in both avian and 2009 pandemic H1N1, although it contained a synonymous mutation in both cases. The codons in 2009 pandemic H1N1 (Figure 1) including 184, 258, and 314 had significant effects on the receptor binding specificity of HA of 2009 pandemic H1N1 [26]. The HA active site located in a cleft is composed of the codons $91,150,152$, $180,187,191$, and 192, and the active site cleft of HA is formed by its right edge (131_GVTAA) and left edge (221_RGQAGR) [27]. Three codons 127(2), 128(1), and 129(2) in Table 2 were near the right edge and codon 225(3) in avian (Figure 1) was on the left edge of the active site.

The importance values of top codons in avian were more homogenous than those in the 2009 pandemic H1N1 and swine. As in case of the amino acid markers [8], the HA1 domain of HA contained more significant codons than the HA2 domain (Figure 1).

\subsubsection{NA Gene}

In comparison of human with avian, 2009 pandemic H1N1, and swine viruses, there were several synonymous mutation positions in NA with high importance. They were 263(3) $(\operatorname{gtg}(\mathrm{V}), \operatorname{gtt}(\mathrm{V}))$ and $410(3)(\mathrm{cca}(\mathrm{P})$, $\operatorname{cct}(\mathrm{P}))$ in avian, 156(1) $(\operatorname{aga}(\mathrm{R}), \operatorname{agg}(\mathrm{R})), 339(3)(\operatorname{act}(\mathrm{T})$, $\operatorname{tcg}(\mathrm{S}))$, and 440(3) $(\operatorname{agt}(\mathrm{S}), \operatorname{agc}(\mathrm{S}))$ in 2009 pandemic H1N1, and 89(3) (tcc(S), tca(S)) and 267(3) $(\mathrm{gtt}(\mathrm{V})$, $\operatorname{ata}(\mathrm{I})$ ) in swine. Furthermore, sequence alignment revealed a deletion at codon 435 in the NA nucleotide sequences of 2009 pandemic H1N1, avian, and swine viruses, causing a very high importance at that codon in avian and swine (Figure 2).

The NA active site is a shallow pocket constructed from conserved residues, some of which contact the substrate directly and participate in catalysis, while others 
Table 2. This table contains the consensus nucleotides (codons) at positions in HA that have high importance in separating 2009 pandemic H1N1, avian H1, and swine H1 from human H1 viruses. The single digit in parenthesis is the position within the codon that was selected by Random Forests. The single letter 'a' (for avian) or 'p' (for pandemic 2009) or 's' (for swine) in parenthesis after a position number indicates whether the position is important for avian or 2009 pandemic H1N1 or swine viruses.

\begin{tabular}{|c|c|c|c|c|c|c|c|c|c|c|c|c|c|}
\hline Position & 45(3) (a) & $71(2)(\mathrm{p})$ & $72(1)(s)$ & $74(1)(s)$ & 94(1)(s) & $127(2)(s)$ & $128(1)(p)$ & $129(2)(\mathrm{s})$ & 139(1)(a) & 141(2)(s) & 152(2)(s) & $157(2)(s)$ & $168(1)(p)$ \\
\hline Avian & $\operatorname{aat}(\mathrm{N})$ & $\operatorname{ctc}(\mathrm{L})$ & $\operatorname{act}(\mathrm{T})$ & $\operatorname{aac}(\mathrm{N})$ & gaa(E) & $\operatorname{gag}(\mathrm{E})$ & $\operatorname{aca}(\mathrm{T})$ & $\operatorname{act}(\mathrm{T})$ & $\operatorname{tct}(\mathrm{S})$ & $\operatorname{gcc}(\mathrm{A})$ & $\operatorname{aca}(\mathrm{T})$ & $\operatorname{tca}(\mathrm{S})$ & $\operatorname{aat}(\mathrm{N})$ \\
\hline Human & aaa $(\mathrm{K})$ & $\operatorname{att}(\mathrm{I})$ & $\operatorname{tcc}(\mathrm{S})$ & gaa(E) & $\operatorname{tat}(\mathrm{Y})$ & $\operatorname{acc}(\mathrm{T})$ & $\operatorname{gta}(V)$ & $\operatorname{acc}(\mathrm{T})$ & $\operatorname{aat}(\mathrm{N})$ & aaa(K) & $\operatorname{acg}(\mathrm{T})$ & $\operatorname{ttg}(\mathrm{L})$ & $\operatorname{aac}(\mathrm{N})$ \\
\hline 2009 H1N1 & aga(R) & $\operatorname{tcc}(\mathrm{S})$ & $\operatorname{aca}(\mathrm{T})$ & $\operatorname{agc}(S)$ & $\operatorname{gat}(\mathrm{D})$ & $\operatorname{gac}(\mathrm{D})$ & $\operatorname{tcg}(\mathrm{S})$ & $\operatorname{aac}(\mathrm{N})$ & $\operatorname{gct}(\mathrm{A})$ & $\operatorname{gca}(\mathrm{A})$ & $\operatorname{gtt}(V)$ & $\operatorname{tca}(\mathrm{S})$ & $\operatorname{gat}(\mathrm{D})$ \\
\hline Swine & $\operatorname{agg}(\mathrm{R})$ & $\operatorname{ttc}(\mathrm{F})$ & $\mathrm{aca}(\mathrm{T})$ & $\operatorname{agc}(S)$ & $\operatorname{gat}(\mathrm{D})$ & $\operatorname{gaa}(\mathrm{E})$ & $\operatorname{aca}(\mathrm{T})$ & $\operatorname{aac}(\mathrm{N})$ & $\operatorname{gct}(\mathrm{A})$ & $\operatorname{gca}(\mathrm{A})$ & $\operatorname{gta}(V)$ & $\operatorname{tca}(\mathrm{S})$ & $\operatorname{aat}(\mathrm{N})$ \\
\hline Position & $205(3)(s)$ & $216(2)(p)$ & $235(3)(a)$ & $236(2)(a)$ & $259(2)(a)$ & $275(3)(\mathrm{p})$ & $298(1)(p)$ & $302(1)(p)$ & $314(1)(p)$ & $365(2)(\mathrm{p})$ & $374(2)(\mathrm{p})$ & 404(3)(a) & $472(1)(\mathrm{s})$ \\
\hline Avian & $\operatorname{aag}(\mathrm{K})$ & $\operatorname{gct}(\mathrm{A})$ & $\operatorname{gac}(\mathrm{D})$ & caa(Q) & $\operatorname{aag}(\mathrm{K})$ & $\operatorname{tgc}(C)$ & atc(I) & gaa(E) & $\operatorname{atg}(\mathrm{M})$ & $\operatorname{cag}(\mathrm{Q})$ & $\operatorname{gga}(\mathrm{G})$ & $\operatorname{att}(\mathrm{I})$ & $\operatorname{gat}(\mathrm{D})$ \\
\hline Human & $\operatorname{cat}(\mathrm{H})$ & $\mathrm{aaa}(\mathrm{K})$ & $\operatorname{gaa}(\mathrm{E})$ & $\operatorname{ccc}(\mathrm{P})$ & $\operatorname{aga}(\mathrm{R})$ & $\operatorname{tgt}(\mathrm{C})$ & $\operatorname{gtc}(V)$ & $\operatorname{gag}(\mathrm{E})$ & $\operatorname{atg}(\mathrm{M})$ & саa(Q) & $\operatorname{ggg}(\mathrm{G})$ & $\operatorname{atg}(\mathrm{M})$ & $\operatorname{aac}(\mathrm{N})$ \\
\hline 2009 H1N1 & $\operatorname{aga}(\mathrm{R})$ & $\operatorname{ata}(\mathrm{I})$ & $\operatorname{gag}(\mathrm{E})$ & $\operatorname{ccg}(\mathrm{P})$ & $\operatorname{aga}(\mathrm{R})$ & $\operatorname{tgc}(C)$ & $\operatorname{atc}(\mathrm{I})$ & aaa $(\mathrm{K})$ & $\operatorname{ctg}(\mathrm{L})$ & $\operatorname{ctg}(\mathrm{L})$ & $\operatorname{gag}(\mathrm{E})$ & ata(I) & $\operatorname{gat}(\mathrm{D})$ \\
\hline Swine & aаa(K) & gca(A) & $\operatorname{gag}(\mathrm{E})$ & $\operatorname{cct}(\mathrm{P})$ & aga(R) & $\operatorname{tgt}(\mathrm{C})$ & $\operatorname{gtc}(\mathrm{V})$ & gaa(E) & $\operatorname{atg}(\mathrm{M})$ & caa(Q) & $\operatorname{ggg}(\mathrm{G})$ & ata(I) & $\operatorname{gat}(\mathrm{D})$ \\
\hline
\end{tabular}

Table 3. This table contains the consensus nucleotides (codons) at positions in NA that have high importance in separating 2009 pandemic H1N1, avian N1, and swine N1 from human N1 viruses. The single digit in parenthesis is the position within the codon that was selected by Random Forests. The single letter ' $a$ ' (for avian) or ' $p$ ' (for pandemic 2009) or 's' (for swine) in parenthesis after a position number indicates whether the position is important for avian or 2009 pandemic H1N1 or swine viruses.

\begin{tabular}{|c|c|c|c|c|c|c|c|c|c|c|c|c|c|}
\hline Position & $126(2)(\mathrm{p})$ & $157(1)(\mathrm{s})$ & $163(3)(\mathrm{s})$ & $166(2)(p)$ & $189(2)(\mathrm{p})$ & $214(3)(a, s)$ & 221(3)(a) & 222(3)(a) & $257(2)(\mathrm{p})$ & $269(1)(p)$ & $285(1)(p)$ & $329(3)(a, s)$ & $331(2)(\mathrm{p})$ \\
\hline Avian & $\operatorname{cac}(\mathrm{H})$ & $\mathrm{aca}(\mathrm{T})$ & $\operatorname{gtg}(\mathrm{V})$ & $\operatorname{gct}(\mathrm{A})$ & $\operatorname{agt}(S)$ & $\operatorname{gac}(\mathrm{D})$ & $\operatorname{aac}(\mathrm{N})$ & $\operatorname{aac}(\mathrm{N})$ & aаa $(\mathrm{K})$ & $\operatorname{ttg}(\mathrm{L})$ & $\operatorname{gcc}(\mathrm{A})$ & $\operatorname{aat}(\mathrm{N})$ & $\operatorname{gga}(\mathrm{G})$ \\
\hline Human & $\operatorname{cac}(\mathrm{H})$ & $\operatorname{gcc}(\mathrm{A})$ & $\operatorname{cta}(\mathrm{L})$ & $\operatorname{gct}(\mathrm{A})$ & $\operatorname{ggc}(\mathrm{G})$ & $\operatorname{gaa}(\mathrm{E})$ & $\operatorname{aag}(\mathrm{K})$ & caa $(Q)$ & $\operatorname{aag}(\mathrm{K})$ & $\operatorname{ttg}(\mathrm{L})$ & $\operatorname{act}(\mathrm{T})$ & aаa $(\mathrm{K})$ & $\operatorname{gga}(\mathrm{G})$ \\
\hline 2009 H1N1 & $\operatorname{ccc}(\mathrm{P})$ & $\operatorname{acc}(\mathrm{T})$ & $\operatorname{att}(\mathrm{I})$ & $\operatorname{gtt}(\mathrm{V})$ & $\operatorname{aat}(\mathrm{N})$ & $\operatorname{gac}(\mathrm{D})$ & $\operatorname{aac}(\mathrm{N})$ & $\operatorname{aat}(\mathrm{N})$ & $\operatorname{aga}(\mathrm{R})$ & $\operatorname{atg}(\mathrm{M})$ & $\operatorname{tct}(\mathrm{S})$ & $\operatorname{aat}(\mathrm{N})$ & $\operatorname{aag}(\mathrm{K})$ \\
\hline Swine & $\operatorname{cac}(\mathrm{H})$ & $\operatorname{acc}(\mathrm{T})$ & $\operatorname{att}(\mathrm{I})$ & $\operatorname{gct}(\mathrm{A})$ & $\operatorname{gga}(\mathrm{G})$ & $\operatorname{gat}(\mathrm{D})$ & $\operatorname{aac}(\mathrm{N})$ & aаa $(\mathrm{K})$ & aaa $(\mathrm{K})$ & $\operatorname{ctg}(\mathrm{L})$ & $\mathrm{aca}(\mathrm{T})$ & $\operatorname{aat}(\mathrm{N})$ & $\operatorname{ggg}(\mathrm{G})$ \\
\hline Position & $336(1)(\mathrm{s}) 3$ & $340(1)(a, s)$ & $344(1)(a)$ & $351(2)(a)$ & $365(2)(\mathrm{p}, \mathrm{s})$ & $369(2)(a)$ & $395(2)(\mathrm{p})$ & 397(2)(p) & $398(3)(\mathrm{p})$ & $435(1)(a, s)$ & $435(2)(a, s)$ & $435(3)(a, s)$ & \\
\hline Avian & $\operatorname{ggt}(\mathrm{G})$ & $\operatorname{cct}(\mathrm{P})$ & $\operatorname{tat}(\mathrm{Y})$ & $\operatorname{ttt}(\mathrm{F})$ & $\operatorname{act}(\mathrm{T})$ & $\operatorname{agc}(S)$ & $\operatorname{gca}(\mathrm{A})$ & $\operatorname{act}(\mathrm{T})$ & $\operatorname{gat}(\mathrm{D})$ & --- & --- & --- & \\
\hline Human & $\operatorname{aat}(\mathrm{N})$ & $\operatorname{gtt}(V)$ & $\operatorname{aac}(\mathrm{N})$ & $\operatorname{tac}(Y)$ & $\operatorname{aac}(\mathrm{N})$ & $\operatorname{aag}(\mathrm{K})$ & $\operatorname{gca}(\mathrm{A})$ & $\operatorname{act}(\mathrm{T})$ & gat(D) & $\mathrm{aca}(\mathrm{T})$ & $\mathrm{aca}(\mathrm{T})$ & $\mathrm{aca}(\mathrm{T})$ & \\
\hline 2009 H1N1 & $\operatorname{ggt}(\mathrm{G})$ & $\operatorname{tct}(\mathrm{S})$ & $\operatorname{aat}(\mathrm{N})$ & $\operatorname{ttc}(\mathrm{F})$ & $\operatorname{att}(\mathrm{I})$ & $\operatorname{aac}(\mathrm{N})$ & $\operatorname{gga}(\mathrm{G})$ & $\operatorname{aat}(\mathrm{N})$ & $\operatorname{gag}(\mathrm{E})$ & --- & --- & --- & \\
\hline Swine & $\operatorname{ggc}(\mathrm{G})$ & $\operatorname{tct}(\mathrm{S})$ & $\operatorname{aat}(\mathrm{N})$ & $\mathrm{ttt}(\mathrm{F})$ & $\operatorname{atc}(\mathrm{I})$ & $\operatorname{agt}(\mathrm{S})$ & $\operatorname{gca}(\mathrm{A})$ & $\operatorname{act}(\mathrm{T})$ & $\operatorname{gat}(\mathrm{D})$ & --- & --- & --- & \\
\hline
\end{tabular}

provide a structural framework [28]. According to the numbering in [29], these residues of $\mathrm{N} 1$ are 118,119 , $151,152,156,179,180,223,225,228,247,277,278$, 293, 295, 368, and 402. The important codons in Figure 2 including 157(1), 221(3), 222(3), and 369(2) were near these residue positions, and codon 156(1) carrying a synonymous mutation in 2009 pandemic $\mathrm{H} 1 \mathrm{~N} 1$ is at one of these positions.

\subsubsection{M1 Gene}

Residue positions 115, 121, and 137 were avian-human host shift markers in [5]. Codons 103(3), 115(1), 121(1), 137(1), 218(1), 218(3), and 239(1) were identified as avian-human markers in this study and in [8], with codon 218 being selected twice, 218(1) and 218(3). Remarkably, codons 149 and 180 carrying a synonymous mutation had a very higher importance than residue positions 115,121 , and 137.

Residue position 137 was a swine-human marker in [2]. There were codons 115(1), 115(3), 137(1), 218(1), and 218(3) selected as swine-human markers in this study and in [8], and two codons 115 and 218 were chosen 

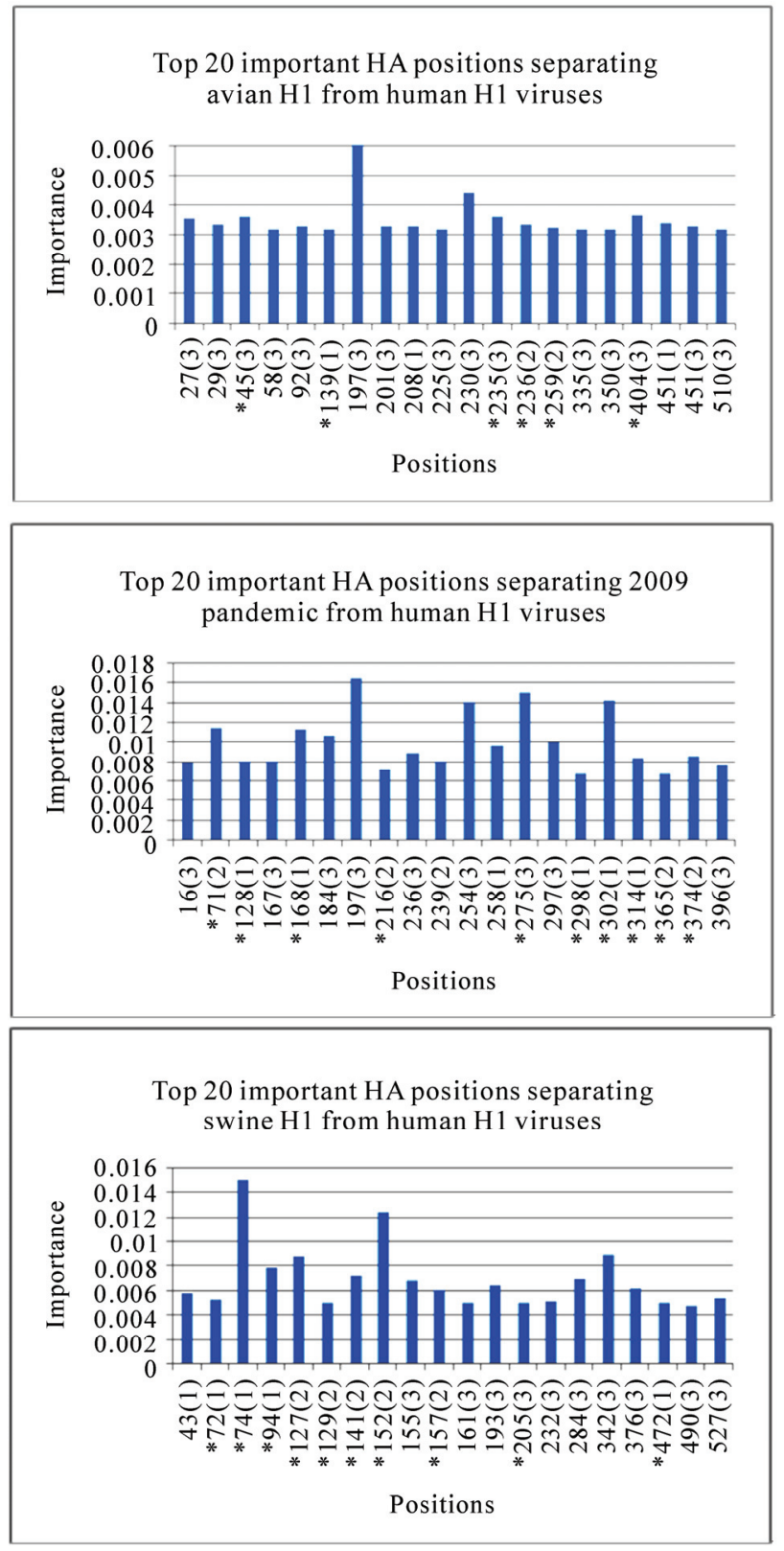

Figure 1. Top important HA codon positions in distinguishing avian H1, human H1, 2009 pandemic H1N1, and swine H1 viruses. The single digit in parenthesis is the position within the codon that was selected by Random Forests. The positions with an asterisk are the important residue positions identified in [8].

twice, i.e., 115(1), 115(3), and 218(1), 218(3). Even though the previously discovered residue position 137 received the highest importance, the two newly found codons 173 and 180 had a very high importance as well. It was noteworthy that codon 180 was significant in both avian and swine and was located in the C-terminal part of M1 (codons 165-252) that bind to vRNP (viral ribonu-
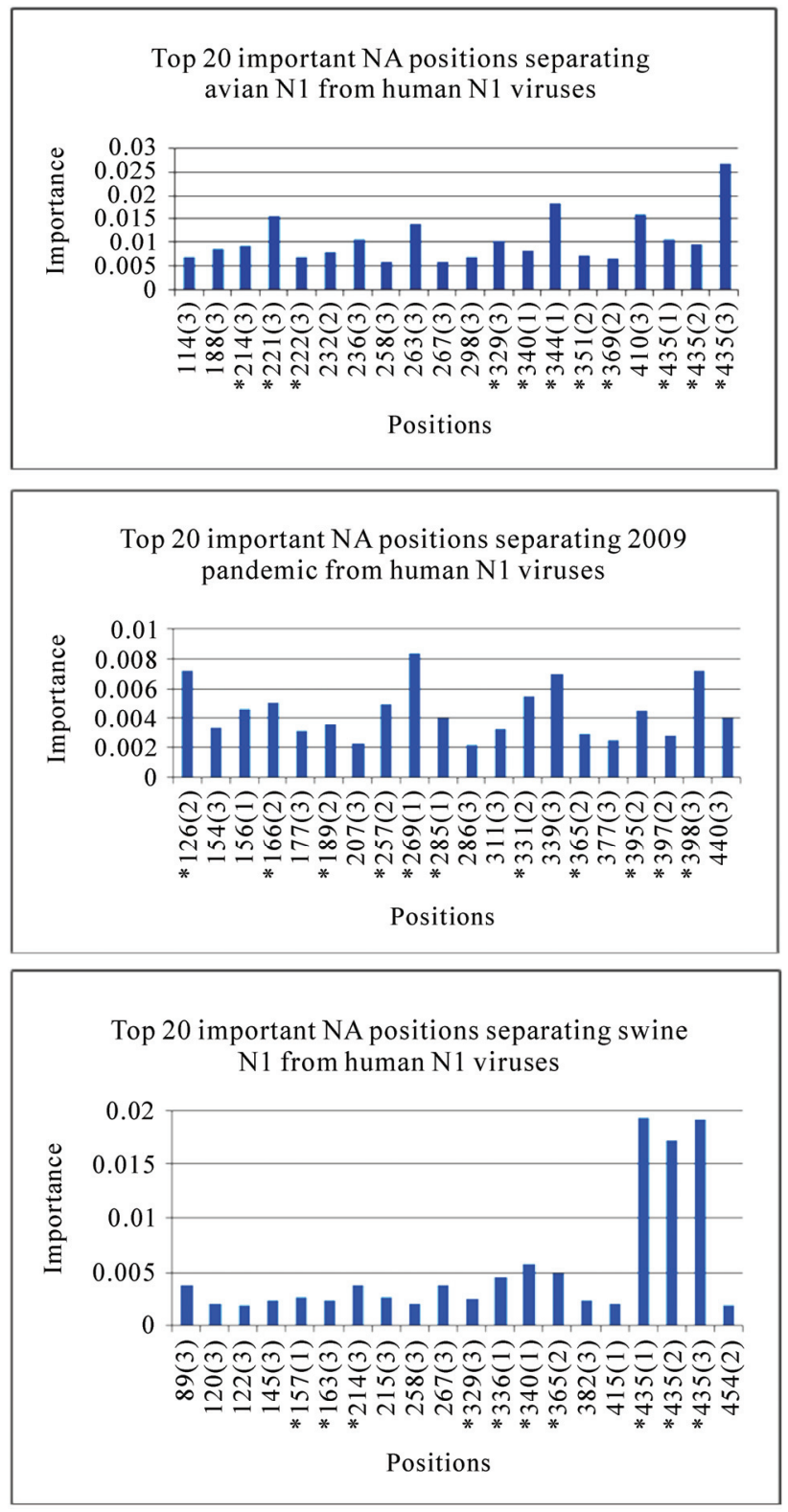

Figure 2. Top important NA codon positions in distinguishing avian N1, human N1, 2009 pandemic H1N1, and swine N1 viruses. The single digit in parenthesis is the position within the codon that was selected by Random Forests. The positions with an asterisk are the important residue positions identified in [8].

cleoproteins) [30] (Figure 3). This study and [8] found that codons 30(1), 30(2), 115(3), 142(3), 166(3), 209(1), 214(3), and 218(3) were important host markers in 2009 pandemic H1N1 with codon 30 being chosen twice.

In comparison of human with avian, 2009 pandemic H1N1, and swine viruses, there were several synonymous mutation positions in M1 with high importance. They were 149(3) (gcc(A), gca(A)) and 180(3) $(\operatorname{gtg}(\mathrm{V})$, 

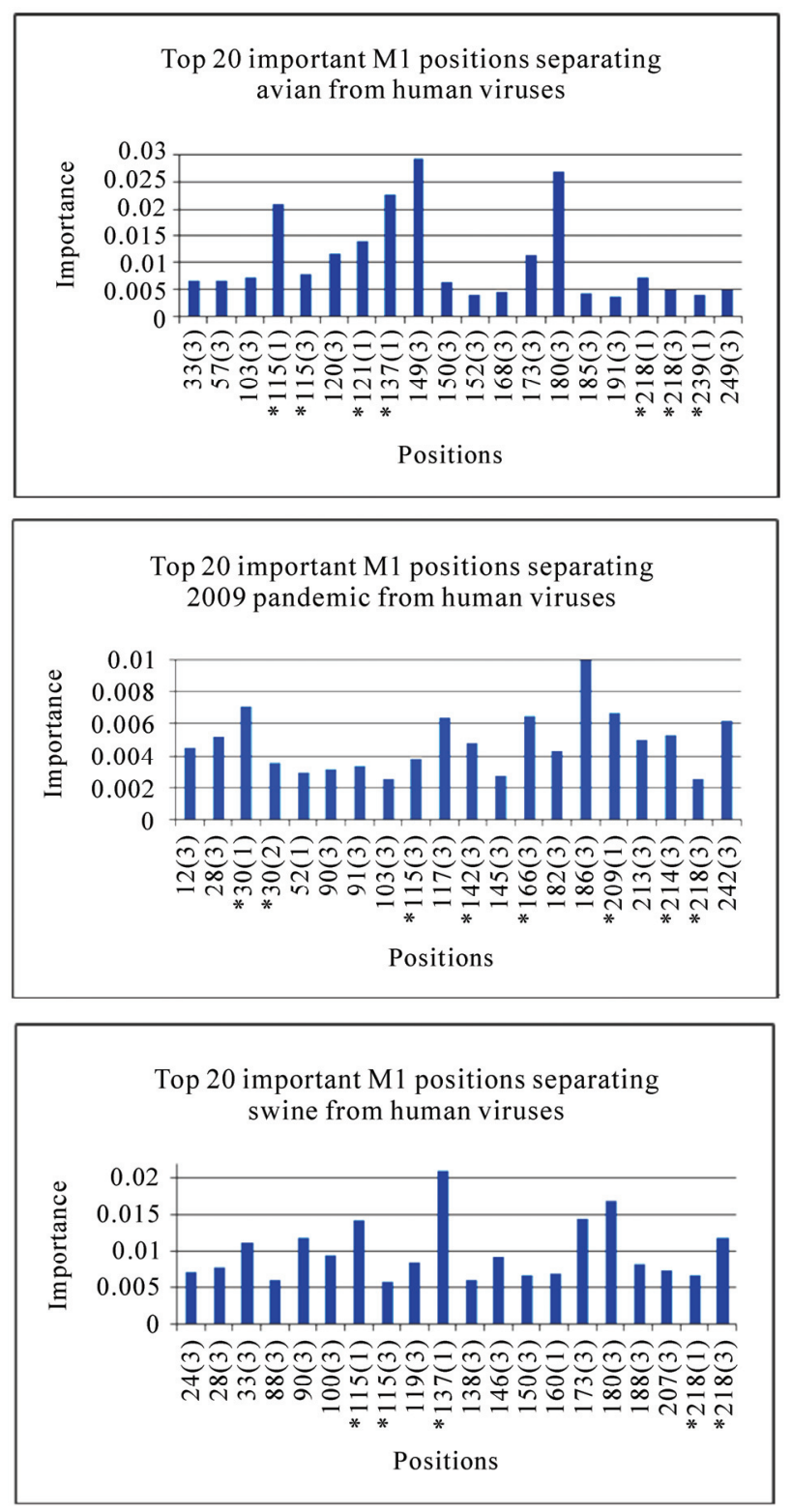

Figure 3. Top important M1 codon positions in distinguishing avian, human, 2009 pandemic H1N1, and swine viruses. The single digit in parenthesis is the position within the codon that was selected by Random Forests. The positions with an asterisk are the important residue positions identified in [8].

$\operatorname{gtt}(\mathrm{V}))$ in avian, 117(3) (cta(L), $\operatorname{ctc}(\mathrm{L})), 186(3)(\mathrm{gct}(\mathrm{A})$, gca(A)), and 242(3) (aaa(K), aag(K)) in 2009 pandemic $\mathrm{H} 1 \mathrm{~N} 1$, and 90(3) $(\operatorname{ccg}(\mathrm{P}), \mathrm{cca}(\mathrm{P})), 173(3)(\operatorname{atc}(\mathrm{I})$, ata(I)) and $180(3)(\mathrm{gta}(\mathrm{V}), \mathrm{gtt}(\mathrm{V}))$ in swine (Figure 3$)$.

\subsubsection{M2 Gene}

This gene has three domains, one N-terminal extracellular domain ( 24 codons) recognized by host immune system, one transmembrane domain (19 codons) responsible for ion channel activity, and one cytoplasmic tail (54
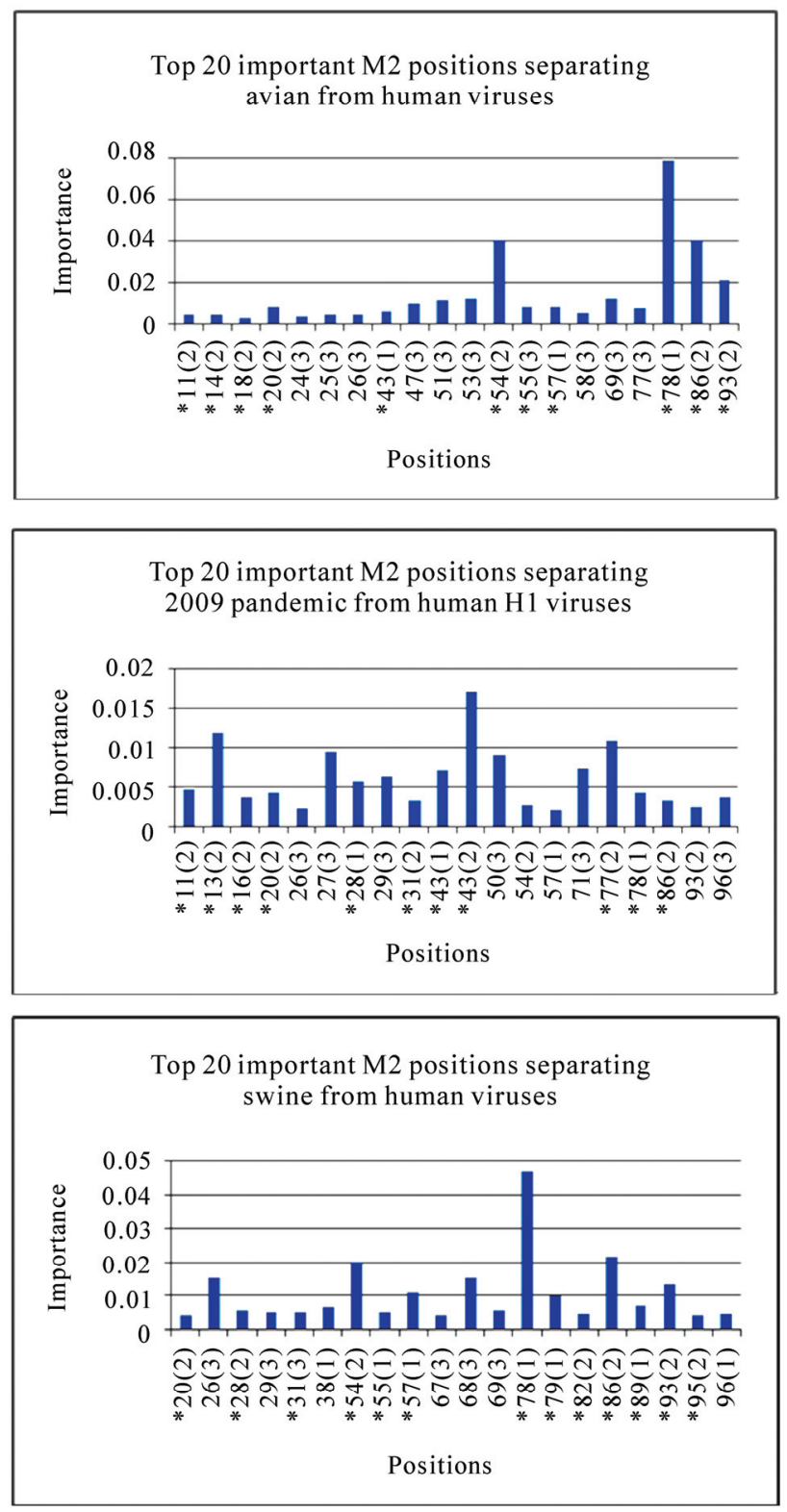

Figure 4. Top important M2 codon positions in distinguishing avian, human, 2009 pandemic H1N1, and swine viruses. The single digit in parenthesis is the position within the codon that was selected by Random Forests. The positions with an asterisk are the important residue positions identified in [8].

codons) interacting with $\mathrm{M} 1$ and required for genome packing and formation of virus particles [31].

Residue positions $11,14,20,28,54,55,57,78$, and 86 were avian-human host shift sites found in [5]. Codons 11(2), 14(2), 18(2), 20(2), 43(1), 54(2), 55(3), 57(1), 78(1), 86(2), and 93(2) were important avianhuman markers in this study and in [8], plus codons 18(2), 43(1), and 93(2) were new markers, with codon 93(2) carrying a high importance. 
Table 4. This table contains the consensus nucleotides (codons) at positions in M1 that have high importance in separating 2009 pandemic H1N1, avian, and swine from human viruses. The single digit in parenthesis is the position within the codon that was selected by Random Forests. The single letter 'a' (for avian) or 'p' (for pandemic 2009) or 's' (for swine) in parenthesis after a position number indicates whether the position is important for avian or 2009 pandemic H1N1 or swine viruses.

\begin{tabular}{|c|c|c|c|c|c|c|c|}
\hline Position & $30(1)(p)$ & $30(2)(p)$ & $115(1)(\mathrm{a}, \mathrm{s})$ & $115(3)(a)$ & $115(3)(\mathrm{p}, \mathrm{s})$ & 121(1)(a) & $137(1)(\mathrm{a}, \mathrm{s})$ \\
\hline Avian & $\operatorname{gat}(\mathrm{D})$ & $\operatorname{gat}(\mathrm{D})$ & $\operatorname{gtt}(\mathrm{V})$ & $\operatorname{gtt}(\mathrm{V})$ & $\operatorname{gtt}(\mathrm{V})$ & $\operatorname{act}(\mathrm{T})$ & $\operatorname{acg}(\mathrm{T})$ \\
\hline Human & $\operatorname{gat}(\mathrm{D})$ & $\operatorname{gat}(\mathrm{D})$ & $\operatorname{ata}(\mathrm{I})$ & $\operatorname{ata}(\mathrm{I})$ & $\operatorname{ata}(\mathrm{I})$ & $\operatorname{gct}(\mathrm{A})$ & $\operatorname{gct}(\mathrm{A})$ \\
\hline 2009 H1N1 & $\operatorname{agt}(\mathrm{S})$ & $\operatorname{agt}(\mathrm{S})$ & $\operatorname{gtg}(V)$ & $\operatorname{gtg}(V)$ & $\operatorname{gtg}(\mathrm{V})$ & $\operatorname{act}(\mathrm{T})$ & $\mathrm{aca}(\mathrm{T})$ \\
\hline Swine & $\operatorname{gat}(\mathrm{D})$ & $\operatorname{gat}(\mathrm{D})$ & $\operatorname{gta}(V)$ & $\operatorname{gta}(V)$ & $\operatorname{gta}(V)$ & $\operatorname{gct}(\mathrm{A})$ & $\operatorname{act}(\mathrm{T})$ \\
\hline Position & $142(3)(\mathrm{p})$ & $166(3)(p)$ & $209(1)(p)$ & $214(3)(p)$ & $218(1)(a, s)$ & $218(3)(a, p, s)$ & $239(1)(a)$ \\
\hline Avian & $\operatorname{gtg}(\mathrm{V})$ & $\operatorname{gtg}(V)$ & $\operatorname{gct}(\mathrm{A})$ & $\operatorname{cag}(\mathrm{Q})$ & $\mathrm{aca}(\mathrm{T})$ & $\mathrm{aca}(\mathrm{T})$ & $\operatorname{gcc}(\mathrm{A})$ \\
\hline Human & $\operatorname{gtg}(\mathrm{V})$ & $\operatorname{gtg}(\mathrm{V})$ & $\operatorname{gcc}(\mathrm{A})$ & $\operatorname{cag}(\mathrm{Q})$ & $\operatorname{gcc}(\mathrm{A})$ & $\operatorname{gcc}(\mathrm{A})$ & $\operatorname{acc}(\mathrm{T})$ \\
\hline 2009 H1N1 & $\operatorname{gct}(\mathrm{A})$ & $\operatorname{gct}(\mathrm{A})$ & $\operatorname{act}(\mathrm{T})$ & $\operatorname{cat}(\mathrm{H})$ & $\operatorname{act}(\mathrm{T})$ & $\operatorname{act}(\mathrm{T})$ & $\operatorname{gcc}(\mathrm{A})$ \\
\hline Swine & $\operatorname{gtg}(\mathrm{V})$ & $\operatorname{gtg}(V)$ & $\operatorname{gct}(\mathrm{A})$ & $\operatorname{cag}(Q)$ & $\mathrm{aca}(\mathrm{T})$ & $\operatorname{aca}(\mathrm{T})$ & $\operatorname{gcc}(\mathrm{A})$ \\
\hline
\end{tabular}

Table 5. This table contains the consensus nucleotides (codons) at positions in M2 that have high importance in separating 2009 pandemic H1N1, avian, and swine from human viruses. The single digit in parenthesis is the position within the codon that was selected by Random Forests. The single letter 'a' (for avian) or 'p' (for pandemic 2009) or 's' (for swine) in parenthesis after a position number indicates whether the position is important for avian or 2009 pandemic H1N1 or swine viruses.

\begin{tabular}{ccccccccccccc}
\hline Position & $11(2)(\mathrm{a}, \mathrm{p})$ & $13(2)(\mathrm{p})$ & $14(2)(\mathrm{a})$ & $16(2)(\mathrm{p})$ & $18(2)(\mathrm{a})$ & $20(2)(\mathrm{a}, \mathrm{p}, \mathrm{s})$ & $28(1)(\mathrm{p})$ & $28(2)(\mathrm{s})$ & $31(2)(\mathrm{p})$ & $31(3)(\mathrm{s})$ & $43(1)(\mathrm{a}, \mathrm{p})$ & $43(2)(\mathrm{p})$ \\
\hline \multirow{2}{*}{ Avian } & $\operatorname{acc}(\mathrm{T})$ & $\operatorname{aac}(\mathrm{N})$ & $\operatorname{gga}(\mathrm{G})$ & $\operatorname{gag}(\mathrm{E})$ & $\operatorname{aga}(\mathrm{R})$ & $\operatorname{agc}(\mathrm{S})$ & $\operatorname{att}(\mathrm{I})$ & $\operatorname{att}(\mathrm{I})$ & $\operatorname{agt}(\mathrm{S})$ & $\operatorname{agt}(\mathrm{S})$ & $\operatorname{ctt}(\mathrm{L})$ & $\operatorname{ctt}(\mathrm{L})$ \\
Human & $\operatorname{atc}(\mathrm{I})$ & $\operatorname{aac}(\mathrm{N})$ & $\operatorname{gaa}(\mathrm{E})$ & $\operatorname{ggg}(\mathrm{G})$ & $\operatorname{aga}(\mathrm{R})$ & $\operatorname{aac}(\mathrm{N})$ & $\operatorname{gtt}(\mathrm{V})$ & $\operatorname{gtt}(\mathrm{V})$ & $\operatorname{agt}(\mathrm{S})$ & $\operatorname{agt}(\mathrm{S})$ & $\operatorname{ctt}(\mathrm{L})$ & $\operatorname{ctt}(\mathrm{L})$ \\
2009 H1N1 & $\operatorname{acc}(\mathrm{T})$ & $\operatorname{agc}(\mathrm{S})$ & $\operatorname{gaa}(\mathrm{E})$ & $\operatorname{gag}(\mathrm{E})$ & $\operatorname{aga}(\mathrm{R})$ & $\operatorname{agc}(\mathrm{S})$ & $\operatorname{att}(\mathrm{I})$ & $\operatorname{att}(\mathrm{I})$ & $\operatorname{aat}(\mathrm{N})$ & $\operatorname{aat}(\mathrm{N})$ & $\operatorname{act}(\mathrm{T})$ & $\operatorname{act}(\mathrm{T})$ \\
Swine & $\operatorname{acc}(\mathrm{T})$ & $\operatorname{aac}(\mathrm{N})$ & $\operatorname{gga}(\mathrm{G})$ & $\operatorname{gag}(\mathrm{E})$ & $\operatorname{aga}(\mathrm{R})$ & $\operatorname{aac}(\mathrm{N})$ & $\operatorname{gtt}(\mathrm{V})$ & $\operatorname{gtt}(\mathrm{V})$ & $\operatorname{agc}(\mathrm{S})$ & $\operatorname{agc}(\mathrm{S})$ & $\operatorname{ctt}(\mathrm{L})$ & $\operatorname{ctt}(\mathrm{L})$ \\
\hline Position & $54(2)(\mathrm{a}, \mathrm{s})$ & $55(1)(\mathrm{s})$ & $55(3)(\mathrm{a})$ & $57(1)(\mathrm{a}, \mathrm{s})$ & $77(2)(\mathrm{p})$ & $78(1)(\mathrm{a}, \mathrm{p}, \mathrm{s})$ & $79(1)(\mathrm{s})$ & $82(2)(\mathrm{s})$ & $86(2)(\operatorname{ag}, \mathrm{p}, \mathrm{s})$ & $89(1)(\mathrm{s})$ & $93(2)(\mathrm{a}, \mathrm{s})$ & $95(2)(\mathrm{s})$ \\
\hline \multirow{2}{*}{ Avian } & $\operatorname{cgc}(\mathrm{R})$ & $\operatorname{ctt}(\mathrm{L})$ & $\operatorname{ctt}(\mathrm{L})$ & $\operatorname{tac}(\mathrm{Y})$ & $\operatorname{cgg}(\mathrm{R})$ & $\operatorname{cag}(\mathrm{Q})$ & $\operatorname{gaa}(\mathrm{E})$ & $\operatorname{agt}(\mathrm{S})$ & $\operatorname{gtt}(\mathrm{V})$ & $\operatorname{ggt}(\mathrm{G})$ & $\operatorname{aac}(\mathrm{N})$ & $\operatorname{gag}(\mathrm{E})$ \\
Human & $\operatorname{ctc}(\mathrm{L})$ & $\operatorname{ttc}(\mathrm{F})$ & $\operatorname{ttc}(\mathrm{F})$ & $\operatorname{cac}(\mathrm{H})$ & $\operatorname{cga}(\mathrm{R})$ & $\operatorname{aag}(\mathrm{K})$ & $\operatorname{gaa}(\mathrm{E})$ & $\operatorname{aat}(\mathrm{N})$ & $\operatorname{gct}(\mathrm{A})$ & $\operatorname{agt}(\mathrm{S})$ & $\operatorname{agc}(\mathrm{S})$ & $\operatorname{gag}(\mathrm{E})$ \\
$2009 \mathrm{H} 1 \mathrm{N1}$ & $\operatorname{cgc}(\mathrm{R})$ & $\operatorname{ttt}(\mathrm{F})$ & $\operatorname{ttt}(\mathrm{F})$ & $\operatorname{tac}(\mathrm{Y})$ & $\operatorname{caa}(\mathrm{Q})$ & $\operatorname{cag}(\mathrm{Q})$ & $\operatorname{gaa}(\mathrm{E})$ & $\operatorname{agt}(\mathrm{S})$ & $\operatorname{gtt}(\mathrm{V})$ & $\operatorname{ggt}(\mathrm{G})$ & $\operatorname{aac}(\mathrm{N})$ & $\operatorname{gag}(\mathrm{E})$ \\
Swine & $\operatorname{cgc}(\mathrm{R})$ & $\operatorname{ttt}(\mathrm{F})$ & $\operatorname{ttt}(\mathrm{F})$ & $\operatorname{tac}(\mathrm{Y})$ & $\operatorname{cga}(\mathrm{R})$ & $\operatorname{cag}(\mathrm{Q})$ & $\operatorname{aaa}(\mathrm{K})$ & $\operatorname{agt}(\mathrm{S})$ & $\operatorname{gtt}(\mathrm{V})$ & $\operatorname{ggt}(\mathrm{G})$ & $\operatorname{aac}(\mathrm{N})$ & $\operatorname{gag}(\mathrm{E})$ \\
\hline
\end{tabular}

Residue positions 57, 86, and 93 were swine-human shift markers in [32]. Codons 20(2), 28(2), 31(3), 54(2), 55(1), 57(1), 78(1), 79(1), 82(2), 86(2), 89(1), 93(2), and 95(2) were primary swine-human markers in this study and in [8], and in particular codon 78(1) was new and had a much higher importance than the residue positions 57 , 86 , and 93 discovered in [32]. Similarly, codons 11(2), 13(2), 16(2), 20(2), 28(1), 31(2), 43(1), 43(2), 77(2), $78(1)$, and 86(2) were major host markers in 2009 pandemic H1N1 in this study and in [8].
In comparison of human with avian, 2009 pandemic H1N1, and swine viruses, there were several synonymous mutation positions in M2 with high importance. They were 53(3) $(\operatorname{cgt}(\mathrm{R}), \operatorname{cga}(\mathrm{R}))$ in avian, 27(3) $(\mathrm{gtc}(\mathrm{V})$, $\operatorname{gtt}(\mathrm{V}))$ and $50(3)(\operatorname{tgt}(\mathrm{C}), \operatorname{tgc}(\mathrm{C}))$ in 2009 pandemic $\mathrm{H} 1 \mathrm{~N} 1$, and $26(3)(\operatorname{ctc}(\mathrm{L}), \operatorname{ctt}(\mathrm{L}))$ and $68(3)(\mathrm{gtg}(\mathrm{V})$, $\operatorname{gta}(\mathrm{V}))$ in swine (Figure 4).

Figure 4 indicated that codons 20(2), 78(1), 86(2) were significant in all three categories: 2009 pandemic H1N1, avian, and swine, also codon 20(2) was in the N-terminal 


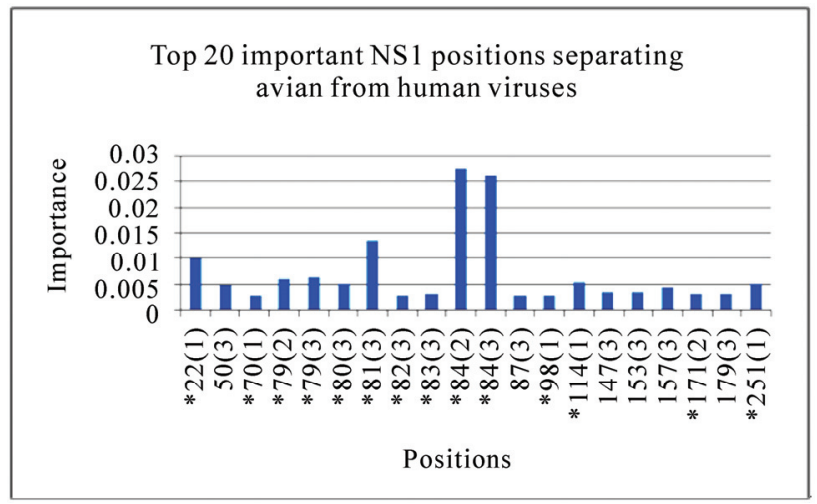

Top 20 important NS1 positions separating 2009 pandemic from human $\mathrm{H} 1$ viruses
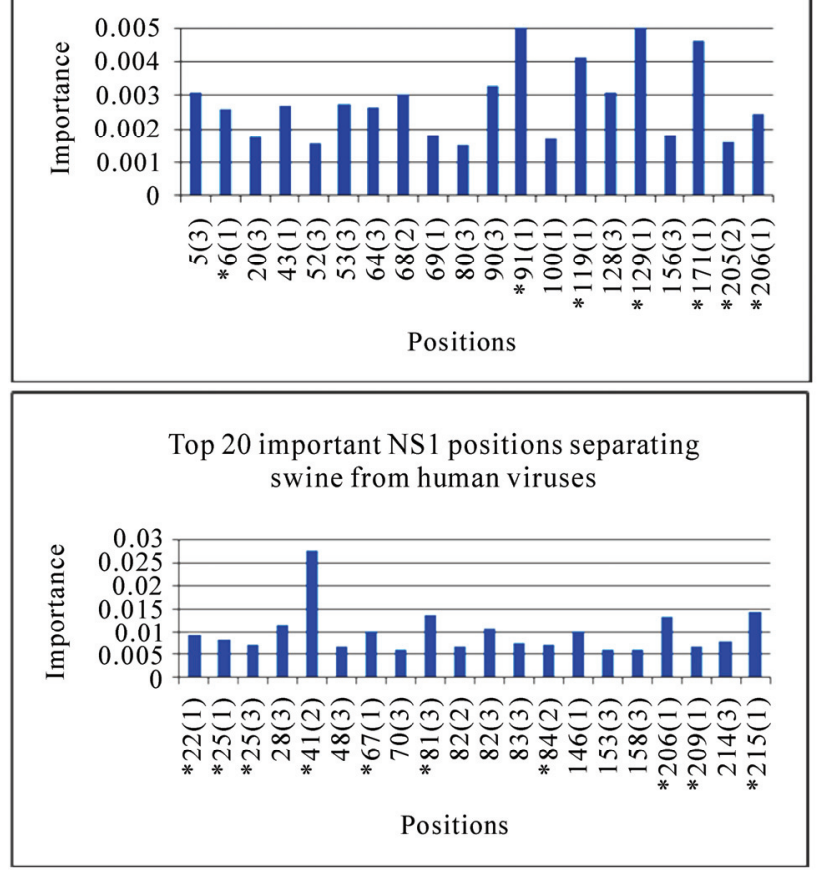

Figure 5. Top important NS1 codon positions in distinguishing avian, human, 2009 pandemic H1N1, and swine viruses. The single digit in parenthesis is the position within the codon that was selected by Random Forests. The positions with an asterisk are the important residue positions identified in [8].

extracellular domain and codons 78(1) and 86(2) in the cytoplasmic tail.

\subsubsection{NS1 Gene}

NS1 is a multifunctional gene [33]. Its N-terminal region has an RNA-binding domain (codons 1-73) and its C-terminal region (codons 74-237) contains the effector domain that inhibits the maturation and exportation of the host cellular antiviral mRNAs [34].

Residue positions 22, 60,81, 84, 215, and 227 were avian-human host shift markers in [4]. Codons 22(1),
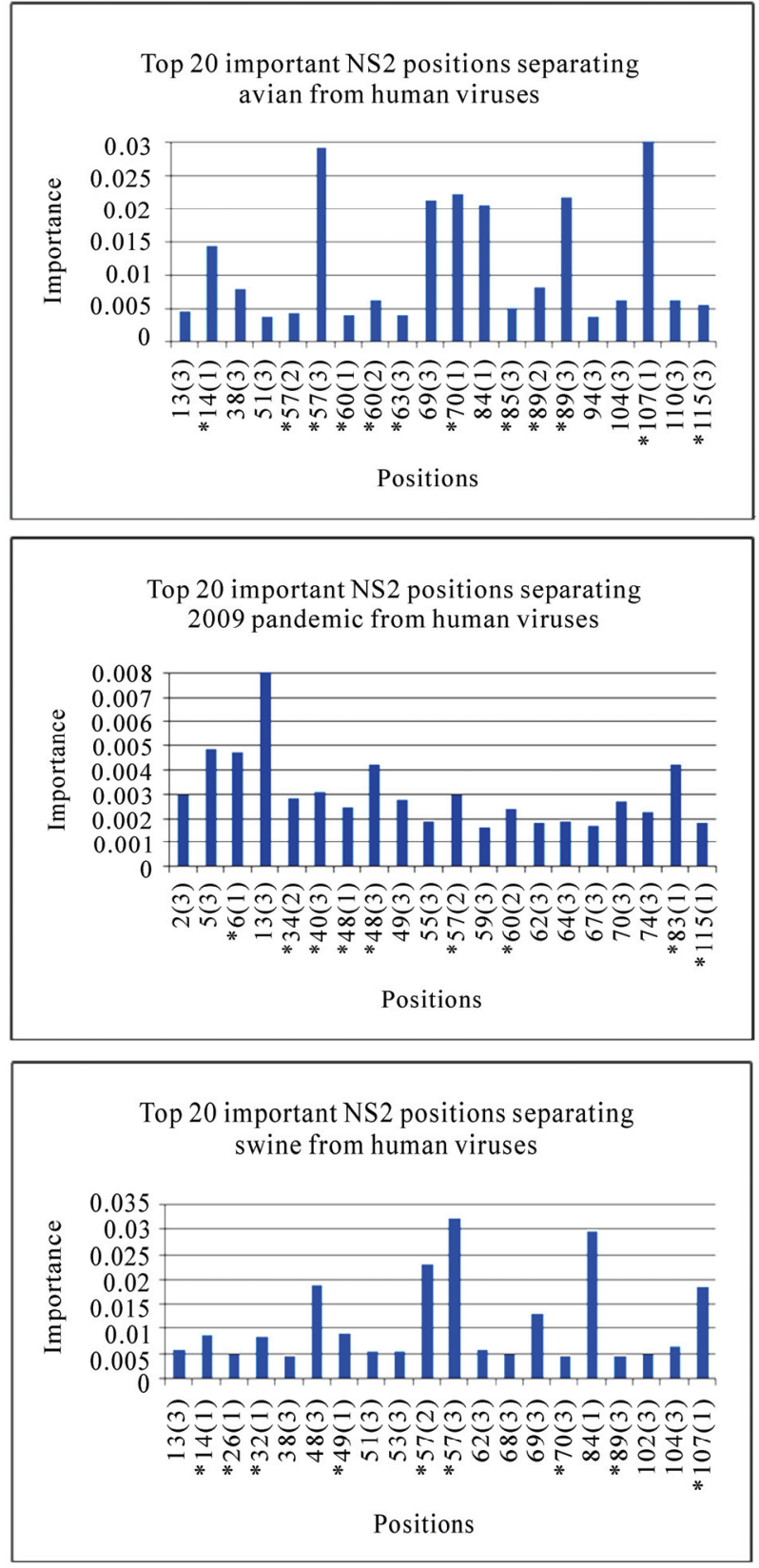

Figure 6. Top important NS2 codon positions in distinguishing avian, human, 2009 pandemic H1N1, and swine viruses. The single digit in parenthesis is the position within the codon that was selected by Random Forests. The positions with an asterisk are the important residue positions identified in [8].

70(1), 79(2), 79(3), 80(3), 81(3), 84(2), 84(3), 98(1), 114(1), 171(2), and 215(1) were significant avian-human markers in this study and in [8] (Figure 5). Furthermore, our analysis selected two positions 2 and 3 within codon 84 with a much higher importance than the previous residue positions $22,60,81,215$, and 227 discovered in [4]. Another codon had two positions selected at 79(2) 
Table 6. This table contains the consensus nucleotides (codons) at positions in NS1 that have high importance in separating 2009 pandemic H1N1, avian, and swine from human viruses. The single digit in parenthesis is the position within the codon that was selected by Random Forests. The single letter ' $a$ ' (for avian) or 'p' (for pandemic 2009) or 's' (for swine) in parenthesis after a position number indicates whether the position is important for avian or 2009 pandemic H1N1 or swine viruses.

\begin{tabular}{ccccccccccccc}
\hline Position & $6(1)(\mathrm{p})$ & $22(1)(\mathrm{a}, \mathrm{s})$ & $25(1)(\mathrm{s})$ & $25(3)(\mathrm{s})$ & $41(2)(\mathrm{s})$ & $67(1)(\mathrm{s})$ & $70(1)(\mathrm{a})$ & $79(2)(\mathrm{a})$ & $79(3)(\mathrm{a})$ & $80(3)(\mathrm{a})$ & $81(3)(\mathrm{a}, \mathrm{s})$ & $82(3)(\mathrm{a})$ \\
\hline \multirow{2}{*}{ Avian } & $\operatorname{gtg}(\mathrm{V})$ & $\operatorname{ttt}(\mathrm{F})$ & $\operatorname{caa}(\mathrm{Q})$ & $\operatorname{caa}(\mathrm{Q})$ & $\operatorname{aag}(\mathrm{K})$ & $\operatorname{cgg}(\mathrm{R})$ & $\operatorname{gag}(\mathrm{E})$ & $\operatorname{atg}(\mathrm{M})$ & $\operatorname{atg}(\mathrm{M})$ & $\operatorname{act}(\mathrm{T})$ & $\operatorname{att}(\mathrm{I})$ & $\operatorname{gct}(\mathrm{A})$ \\
\multirow{2}{*}{ Human } & $\operatorname{gtg}(\mathrm{V})$ & $\operatorname{gtt}(\mathrm{V})$ & $\operatorname{caa}(\mathrm{Q})$ & $\operatorname{caa}(\mathrm{Q})$ & $\operatorname{aag}(\mathrm{K})$ & $\operatorname{agg}(\mathrm{R})$ & $\operatorname{aag}(\mathrm{K})$ & $\operatorname{atg}(\mathrm{M})$ & $\operatorname{atg}(\mathrm{M})$ & $\operatorname{acc}(\mathrm{T})$ & $\operatorname{atg}(\mathrm{M})$ & $\operatorname{gcc}(\mathrm{A})$ \\
2009 H1N1 & $\operatorname{atg}(\mathrm{M})$ & $\operatorname{ttt}(\mathrm{F})$ & $\operatorname{aat}(\mathrm{N})$ & $\operatorname{aat}(\mathrm{N})$ & $\operatorname{aag}(\mathrm{K})$ & $\operatorname{tgg}(\mathrm{W})$ & $\operatorname{aaa}(\mathrm{K})$ & $\operatorname{atg}(\mathrm{M})$ & $\operatorname{atg}(\mathrm{M})$ & $\operatorname{aca}(\mathrm{T})$ & $\operatorname{att}(\mathrm{I})$ & $\operatorname{gca}(\mathrm{A})$ \\
Swine & $\operatorname{gtg}(\mathrm{V})$ & $\operatorname{ttt}(\mathrm{F})$ & $\operatorname{aat}(\mathrm{N})$ & $\operatorname{aat}(\mathrm{N})$ & $\operatorname{aag}(\mathrm{K})$ & $\operatorname{tgg}(\mathrm{W})$ & $\operatorname{aaa}(\mathrm{K})$ & $\operatorname{atg}(\mathrm{M})$ & $\operatorname{atg}(\mathrm{M})$ & $\operatorname{acc}(\mathrm{T})$ & $\operatorname{att}(\mathrm{I})$ & $\operatorname{gca}(\mathrm{A})$ \\
\hline Position & $84(2)(\mathrm{a}, \mathrm{s})$ & $84(3)(\mathrm{a})$ & $91(1)(\mathrm{p})$ & $98(1)(\mathrm{a})$ & $114(1)(\mathrm{a})$ & $119(1)(\mathrm{p})$ & $129(1)(\mathrm{p})$ & $171(1)(\mathrm{p})$ & $171(2)(\mathrm{a})$ & $205(2)(\mathrm{p})$ & $206(1)(\mathrm{p}, \mathrm{s})$ & $209(1)(\mathrm{s})$ \\
\hline Avian & $\operatorname{gtg}(\mathrm{V})$ & $\operatorname{gtg}(\mathrm{V})$ & $\operatorname{act}(\mathrm{T})$ & $\operatorname{atg}(\mathrm{M})$ & $\operatorname{tcc}(\mathrm{S})$ & $\operatorname{atg}(\mathrm{M})$ & $\operatorname{ata}(\mathrm{I})$ & $\operatorname{gat}(\mathrm{D})$ & $\operatorname{gat}(\mathrm{D})$ & $\operatorname{agc}(\mathrm{S})$ & $\operatorname{agt}(\mathrm{S})$ & $\operatorname{gat}(\mathrm{D})$ \\
Human & $\operatorname{aca}(\mathrm{T})$ & $\operatorname{aca}(\mathrm{T})$ & $\operatorname{act}(\mathrm{T})$ & $\operatorname{ttg}(\mathrm{L})$ & $\operatorname{cct}(\mathrm{P})$ & $\operatorname{atg}(\mathrm{M})$ & $\operatorname{atg}(\mathrm{M})$ & $\operatorname{att}(\mathrm{I})$ & $\operatorname{att}(\mathrm{I})$ & $\operatorname{agc}(\mathrm{S})$ & $\operatorname{agt}(\mathrm{S})$ & $\operatorname{aat}(\mathrm{N})$ \\
2009 H1N1 & $\operatorname{gta}(\mathrm{V})$ & $\operatorname{gta}(\mathrm{V})$ & $\operatorname{tct}(\mathrm{S})$ & $\operatorname{atg}(\mathrm{M})$ & $\operatorname{cct}(\mathrm{P})$ & $\operatorname{ttg}(\mathrm{L})$ & $\operatorname{gta}(\mathrm{V})$ & $\operatorname{tat}(\mathrm{Y})$ & $\operatorname{tat}(\mathrm{Y})$ & $\operatorname{aac}(\mathrm{N})$ & $\operatorname{tgt}(\mathrm{C})$ & $\operatorname{aat}(\mathrm{N})$ \\
Swine & $\operatorname{gta}(\mathrm{V})$ & $\operatorname{gta}(\mathrm{V})$ & $\operatorname{gct}(\mathrm{A})$ & $\operatorname{atg}(\mathrm{M})$ & $\operatorname{tct}(\mathrm{S})$ & $\operatorname{atg}(\mathrm{M})$ & $\operatorname{ata}(\mathrm{I})$ & $\operatorname{gat}(\mathrm{D})$ & $\operatorname{gat}(\mathrm{D})$ & $\operatorname{agc}(\mathrm{S})$ & $\operatorname{cgt}(\mathrm{R})$ & $\operatorname{gat}(\mathrm{D})$ \\
\hline
\end{tabular}

Table 7. This table contains the consensus nucleotides (codons) at positions in NS2 that have high importance in separating 2009 pandemic H1N1, avian, and swine from human viruses. The single digit in parenthesis is the position within the codon that was selected by Random Forests. The single letter ' $a$ ' (for avian) or 'p' (for pandemic 2009) or 's' (for swine) in parenthesis after a position number indicates whether the position is important for avian or 2009 pandemic H1N1 or swine viruses.

\begin{tabular}{ccccccccccccc}
\hline Position & $6(1)(\mathrm{p})$ & $14(1)(\mathrm{a}, \mathrm{s})$ & $26(1)(\mathrm{s})$ & $32(1)(\mathrm{s})$ & $34(2)(\mathrm{p})$ & $40(3)(\mathrm{p})$ & $48(1)(\mathrm{p})$ & $48(3)(\mathrm{p})$ & $49(1)(\mathrm{s})$ & $57(2)(\mathrm{a}, \mathrm{p}, \mathrm{s})$ & $57(3)(\mathrm{a}, \mathrm{s})$ & $60(1)(\mathrm{a})$ \\
\hline \multirow{2}{*}{ Avian } & $\operatorname{gtg}(\mathrm{V})$ & $\operatorname{atg}(\mathrm{M})$ & $\operatorname{gag}(\mathrm{E})$ & $\operatorname{ata}(\mathrm{I})$ & $\operatorname{cag}(\mathrm{Q})$ & $\operatorname{ctc}(\mathrm{L})$ & $\operatorname{gca}(\mathrm{A})$ & $\operatorname{gca}(\mathrm{A})$ & $\operatorname{gtg}(\mathrm{V})$ & $\operatorname{tcc}(\mathrm{S})$ & $\operatorname{tcc}(\mathrm{S})$ & $\operatorname{agc}(\mathrm{S})$ \\
Human & $\operatorname{gtg}(\mathrm{V})$ & $\operatorname{tg}(\mathrm{L})$ & $\operatorname{gag}(\mathrm{E})$ & $\operatorname{ata}(\mathrm{I})$ & $\operatorname{cag}(\mathrm{Q})$ & $\operatorname{atc}(\mathrm{I})$ & $\operatorname{gca}(\mathrm{A})$ & $\operatorname{gca}(\mathrm{A})$ & $\operatorname{gta}(\mathrm{V})$ & $\operatorname{tta}(\mathrm{L})$ & $\operatorname{tta}(\mathrm{L})$ & $\operatorname{aac}(\mathrm{N})$ \\
2009 H1N1 & $\operatorname{atg}(\mathrm{M})$ & $\operatorname{atg}(\mathrm{M})$ & $\operatorname{gag}(\mathrm{E})$ & $\operatorname{gta}(\mathrm{V})$ & $\operatorname{cgg}(\mathrm{R})$ & $\operatorname{ata}(\mathrm{I})$ & $\operatorname{act}(\mathrm{T})$ & $\operatorname{act}(\mathrm{T})$ & $\operatorname{gtg}(\mathrm{V})$ & $\operatorname{tac}(\mathrm{Y})$ & $\operatorname{tac}(\mathrm{Y})$ & $\operatorname{agc}(\mathrm{S})$ \\
Swine & $\operatorname{gtg}(\mathrm{V})$ & $\operatorname{atg}(\mathrm{M})$ & $\operatorname{gag}(\mathrm{E})$ & $\operatorname{gta}(\mathrm{V})$ & $\operatorname{cag}(\mathrm{Q})$ & $\operatorname{atc}(\mathrm{I})$ & $\operatorname{gcc}(\mathrm{A})$ & $\operatorname{gcc}(\mathrm{A})$ & $\operatorname{gta}(\mathrm{V})$ & $\operatorname{tac}(\mathrm{Y})$ & $\operatorname{tac}(\mathrm{Y})$ & $\operatorname{aac}(\mathrm{N})$ \\
\hline \multirow{2}{*}{ Position } & $60(2)(\mathrm{a}, \mathrm{p})$ & $63(3)(\mathrm{a})$ & $70(1)(\mathrm{a})$ & $70(3)(\mathrm{s})$ & $83(1)(\mathrm{p})$ & $85(3)(\mathrm{a})$ & $89(2)(\mathrm{a})$ & $89(3)(\mathrm{a}, \mathrm{s})$ & $107(1)(\mathrm{a}, \mathrm{s})$ & $115(1)(\mathrm{p})$ & $115(3)(\mathrm{a})$ & \\
\hline Avian & $\operatorname{agc}(\mathrm{S})$ & $\operatorname{gga}(\mathrm{G})$ & $\operatorname{agt}(\mathrm{S})$ & $\operatorname{agt}(\mathrm{S})$ & $\operatorname{gtg}(\mathrm{V})$ & $\operatorname{cat}(\mathrm{H})$ & $\operatorname{att}(\mathrm{I})$ & $\operatorname{att}(\mathrm{I})$ & $\operatorname{ctt}(\mathrm{L})$ & $\operatorname{act}(\mathrm{T})$ & $\operatorname{act}(\mathrm{T})$ \\
Human & $\operatorname{aac}(\mathrm{N})$ & $\operatorname{gga}(\mathrm{G})$ & $\operatorname{ggt}(\mathrm{G})$ & $\operatorname{ggt}(\mathrm{G})$ & $\operatorname{gtg}(\mathrm{V})$ & $\operatorname{cac}(\mathrm{H})$ & $\operatorname{aca}(\mathrm{T})$ & $\operatorname{aca}(\mathrm{T})$ & $\operatorname{ttt}(\mathrm{F})$ & $\operatorname{act}(\mathrm{T})$ & $\operatorname{act}(\mathrm{T})$ \\
2009 H1N1 & $\operatorname{agc}(\mathrm{S})$ & $\operatorname{gaa}(\mathrm{E})$ & $\operatorname{gga}(\mathrm{G})$ & $\operatorname{gga}(\mathrm{G})$ & $\operatorname{atg}(\mathrm{M})$ & $\operatorname{cac}(\mathrm{H})$ & $\operatorname{gcg}(\mathrm{A})$ & $\operatorname{gcg}(\mathrm{A})$ & $\operatorname{ctt}(\mathrm{L})$ & $\operatorname{gct}(\mathrm{A})$ & $\operatorname{gct}(\mathrm{A})$ \\
Swine & $\operatorname{aac}(\mathrm{N})$ & $\operatorname{gaa}(\mathrm{E})$ & $\operatorname{ggt}(\mathrm{G})$ & $\operatorname{ggt}(\mathrm{G})$ & $\operatorname{gtg}(\mathrm{V})$ & $\operatorname{cac}(\mathrm{H})$ & $\operatorname{atg}(\mathrm{M})$ & $\operatorname{atg}(\mathrm{M})$ & $\operatorname{ctt}(\mathrm{L})$ & $\operatorname{act}(\mathrm{T})$ & $\operatorname{act}(\mathrm{T})$
\end{tabular}

and 79(3) as well. Both of these double selected codons were located in the C-terminal region.

The results of this study and [8] suggested that codons 22(1), 25(1), 25(3), 41(2), 67(1), 81(3), 84(2), 206(1), 209(1), and 215(1) were key swine-human markers and codons 6(1), 91(1), 100(1), 119(1), 128(3), 129(1), 171(1), 205(2), and 206(1) were essential host markers in 2009 pandemic (Figure 5).

In comparison of human with avian, 2009 pandemic H1N1, and swine viruses, there were several synony- mous mutation positions in NS1 with high importance. They were $157(3)(\operatorname{gtg}(\mathrm{V})),(\operatorname{gtt}(\mathrm{V}))$ in avian, 5(3) $(\operatorname{acc}(\mathrm{T})),(\operatorname{act}(\mathrm{T})), 68(3)(\operatorname{atc}(\mathrm{I})),(\operatorname{att}(\mathrm{I})), 90(3)(\operatorname{ctt}(\mathrm{L}))$, $\mathrm{cta}(\mathrm{L}))$, and 128(3) (ata(I)), (atc(I)) in 2009 pandemic H1N1, and 146(1) (cta(L)), (tta(L)) in swine (Figure 5).

\subsubsection{NS2 Gene}

Residue positions 60, 70, and 107 were avian-human host shift markers in [4]. Codons 14(1), 57(2), 57(3), 60(1), 60(2), 63(3), 70(1), 85(3), 89(2), 89(3), 107(1), and 115(3) were avian-human markers in this study and 
in [8] with codons 57,60 , and 89 being selected twice. Codons 57(3) and 89(3) were not only new markers but also had a very high importance, comparable to that of positions 70 and 107 in [4] (Figure 6).

Codons 14(1), 26(1), 32(1), 49(1), 57(2), 57(3), 70(3), $89(3)$, and 107(1) were important swine-human markers in this study and in [8] with codon 57 being selected twice. The same analysis also identified codons 16(1), 34(2), 40(3), 48(1), 48(3), 57(2), 60(2), 83(1), and 115(1) as important host markers in 2009 pandemic H1N1, with codon 48 being selected twice.

Notably, there was one codon position 57(2) that was important in all three categories: avian, 2009 pandemic H1N1, and swine, and it was in the M1 binding domain (codons 59-116) [5].

In comparison of human with avian, 2009 pandemic H1N1, and swine viruses, there were several synonymous mutation positions in NS2 with high importance. They were 69(3) $(\operatorname{ttg}(\mathrm{L}), \operatorname{cta}(\mathrm{L}))$ and 84(1) (cga(R), aga(R)) in avian, 5(3) $(\operatorname{acc}(\mathrm{T})$, act(T)) and 13(3) $(\mathrm{ctt}(\mathrm{L})$, cta(L)) in 2009 pandemic H1N1, and 48(3) (gcc(A), gca(A)) and $84(1)(\operatorname{cgg}(\mathrm{R})$, aga(R)) in swine (Figure 6). Furthermore, codons 84(1) and 13(3) received a very high importance in both avian and swine and in 2009 pandemic H1N1, respectively. Codon 84(1) was in the M1 binding domain.

\subsubsection{NP Gene}

Residue positions 16, 33, 61, 100, 136, 214, 283, 305, $313,357,375$, and 423 were avian-human host shift markers in [4]. Codons 16(2), 61(1), 100(1), 100(2), 283(2), 305(1), 305(3), 313(2), 357(1), and 455(3) were significant for discriminating avian and human viruses in this study and in [8] with codons 100 and 305 being chosen twice (Figure 7).

In this study and in [8], codons 16(2), 61(1), 214(2), 283(2), 289(1), 313(2), 372(3), 442(1), and 455(3) were main swine-human markers, and similarly codons 53(3), 289(1), 313(1), 316(3), 430(2), and 444(1) were vital host markers in 2009 pandemic H1N1.

In comparison of human with avian, 2009 pandemic H1N1, and swine viruses, there were several synonymous mutation positions in NP with high importance. They were 108(3) $(\operatorname{ctg}(\mathrm{L}), \operatorname{ctc}(\mathrm{L}))$ and $155(3)(\operatorname{gtg}(\mathrm{V})$, $\operatorname{gtt}(\mathrm{V}))$ in avian, 177(3) $(\operatorname{ggt}(\mathrm{G}), \mathrm{gga}(\mathrm{G})), 182(3)(\mathrm{gcg}(\mathrm{A})$, gca(A)), and 363(3) (gtc(V), gta(V)) in 2009 pandemic H1N1, and 3(3) (tct(S), tcc(S)), 94(3) (gga(G), ggg(G)), and $376(3)(\mathrm{tcc}(\mathrm{S}), \mathrm{tca}(\mathrm{S}))$ in swine (Figure 7).

$\mathrm{NP}$ has three regions (codons 1-160, 256-340 and 340-498) that bind to PB1 and PB2 [35], and codons 108(3) and 155(3) in avian and codons 3(3), 94(3), and $376(3)$ in swine were in two of these three regions. One region, codons 360-374, in NP of 2009 pandemic H1N1 was deemed extremely important for host range restric- tion and is a common feature of pandemic viruses [36], and codon 363(3) carrying a synonymous mutation in 2009 pandemic H1N1 was in this region.

\subsubsection{PA Gene}

Residue positions $28,55,57,65,66,100,225,268,321$, $337,356,382,400,404,409,421$, and 552 were avian-human host shift markers in [4], whereas this study and [8] indicated that codons 55(1), 56(1), 225(1), 337(1), 337(3), 421(2), and 552(2) were important avian-human markers, with codon 337 being chosen twice (Figure 8).

Residue positions 268 and 552 were swine-human markers uncovered in [32]. Codons 225(1), 268(1), 272(1), 337(1), 421(2), and 552(2) were key swinehuman markers in our analysis and in [8] with codon $337(1)$ having a similar importance as position 268. Also codons 85(2), 186(1), 275(2), 277(1), and 388(3) were crucial for classifying 2009 pandemic H1N1 and human viruses in this study and in [8].

The N-terminal domain of PA (codons 1-256) harbors several functional domains, including an endonuclease active site with a putative active site motif, two putative nuclear transport motifs (codons 124-139 (NLS1) and codons 186-247 (NLS2)), and a proteolytic domain that can induce generalized proteolysis of both viral and host proteins. The C-terminal domain of PA (codons 257-716) binds to PB1 for complex formation and nuclear transport [37].

In comparison of human with avian, 2009 pandemic H1N1, and swine viruses, there were several synonymous mutation positions in PA with high importance. They were 106(3) (ctc(L), cta(L)), 138(3) (ata(I), att(I)), and 270(3) $(\operatorname{tta}(\mathrm{L}), \operatorname{ctt}(\mathrm{L}))$ in avian, 44(3) $(\mathrm{gtt}(\mathrm{V}), \mathrm{gta}(\mathrm{V}))$, 173(3) $(\operatorname{act}(\mathrm{T}), \operatorname{acc}(\mathrm{T}))$, and 526(3) $(\operatorname{tca}(\mathrm{S}), \operatorname{tct}(\mathrm{S}))$ in 2009 pandemic H1N1, and 106(3) (ctt(L), cta(L)), 290(3) $(\operatorname{tta}(\mathrm{L}), \operatorname{ttg}(\mathrm{L}))$, and $345(3)(\operatorname{cta}(\mathrm{L}), \operatorname{ttg}(\mathrm{L}))$ in swine (Figure 8). Codon 138(3) was in the first putative nuclear localization signal (NLS1) region, and codons 270(3) and 526(3) were in the C-terminal domain of PA.

\subsubsection{PB1 Gene}

Residue position 336 was the only avian-human host shift markers in [4]. Codons 327(2), 336(1), 361(3), 401(3), and 576(3) were important host markers in avian in this study and in [8] with codons 361(1), 401(3), and 576(3) having a much higher importance than position 336 (Figure 9).

The analysis of this study and [8] suggested that codons 327(2), 339(3), and 638(3) were important swinehuman markers, and codons 12(1), 175(1), 212(1), 339(3), 364(1), 435(2), 618(3), 638(3), 728(1), and 728(3) were vital for classifying 2009 pandemic H1N1 and human viruses with codon 728 being selected twice. 
Table 8. This table contains the consensus nucleotides (codons) at positions in NP that have high importance in separating 2009 pandemic H1N1, avian, and swine from human viruses. The single digit in parenthesis is the position within the codon that was selected by Random Forests. The single letter 'a' (for avian) or 'p' (for pandemic 2009) or 's' (for swine) in parenthesis after a position number indicates whether the position is important for avian or 2009 pandemic H1N1 or swine viruses.

\begin{tabular}{cccccccccccc}
\hline Position & $16(2)(\mathrm{a}, \mathrm{s})$ & $53(3)(\mathrm{p})$ & $\operatorname{61}(1)(\mathrm{a}, \mathrm{s})$ & $\operatorname{100}(1)(\mathrm{a})$ & $100(2)(\mathrm{a})$ & $214(2)(\mathrm{s})$ & $283(2)(\mathrm{a}, \mathrm{s})$ & $289(1)(\mathrm{p}, \mathrm{s})$ & $305(1)(\mathrm{a})$ & $305(3)(\mathrm{a})$ \\
\hline Avian & $\operatorname{ggt}(\mathrm{G})$ & $\operatorname{gaa}(\mathrm{E})$ & $\operatorname{ata}(\mathrm{I})$ & $\operatorname{aga}(\mathrm{R})$ & $\operatorname{aga}(\mathrm{R})$ & $\operatorname{aga}(\mathrm{R})$ & $\operatorname{ctt}(\mathrm{L})$ & $\operatorname{tat}(\mathrm{Y})$ & $\operatorname{cgt}(\mathrm{R})$ & $\operatorname{cgt}(\mathrm{R})$ \\
Human & $\operatorname{gat}(\mathrm{D})$ & $\operatorname{gaa}(\mathrm{E})$ & $\operatorname{ttg}(\mathrm{L})$ & $\operatorname{gta}(\mathrm{V})$ & $\operatorname{gta}(\mathrm{V})$ & $\operatorname{aaa}(\mathrm{K})$ & $\operatorname{cct}(\mathrm{P})$ & $\operatorname{tac}(\mathrm{Y})$ & $\operatorname{aaa}(\mathrm{K})$ & $\operatorname{aaa}(\mathrm{K})$ \\
2009 H1N1 & $\operatorname{ggt}(\mathrm{G})$ & $\operatorname{gat}(\mathrm{D})$ & $\operatorname{ata}(\mathrm{I})$ & $\operatorname{ata}(\mathrm{I})$ & $\operatorname{ata}(\mathrm{I})$ & $\operatorname{agg}(\mathrm{R})$ & $\operatorname{ctt}(\mathrm{L})$ & $\operatorname{cat}(\mathrm{H})$ & $\operatorname{aaa}(\mathrm{K})$ & $\operatorname{aaa}(\mathrm{K})$ \\
Swine & $\operatorname{ggt}(\mathrm{G})$ & $\operatorname{gag}(\mathrm{E})$ & $\operatorname{ata}(\mathrm{I})$ & $\operatorname{gta}(\mathrm{V})$ & $\operatorname{gta}(\mathrm{V})$ & $\operatorname{agg}(\mathrm{R})$ & $\operatorname{ctt}(\mathrm{L})$ & $\operatorname{cat}(\mathrm{H})$ & $\operatorname{aaa}(\mathrm{K})$ & $\operatorname{aaa}(\mathrm{K})$ \\
\hline Position & $313(1)(\mathrm{p})$ & $313(2)(\mathrm{a}, \mathrm{s})$ & $316(3)(\mathrm{p})$ & $355(3)(\mathrm{a})$ & $357(1)(\mathrm{a})$ & $372(3)(\mathrm{s})$ & $430(2)(\mathrm{p})$ & $442(1)(\mathrm{s})$ & $444(1)(\mathrm{p})$ & $455(3)(\mathrm{s})$ \\
\hline \multirow{2}{*}{ Avian } & $\operatorname{ttc}(\mathrm{F})$ & $\operatorname{ttc}(\mathrm{F})$ & $\operatorname{att}(\mathrm{I})$ & $\operatorname{aga}(\mathrm{R})$ & $\operatorname{caa}(\mathrm{Q})$ & $\operatorname{gaa}(\mathrm{E})$ & $\operatorname{aca}(\mathrm{T})$ & $\operatorname{act}(\mathrm{T})$ & $\operatorname{atc}(\mathrm{I})$ & $\operatorname{gat}(\mathrm{D})$ \\
Human & $\operatorname{tac}(\mathrm{Y})$ & $\operatorname{tac}(\mathrm{Y})$ & $\operatorname{atc}(\mathrm{I})$ & $\operatorname{cgg}(\mathrm{R})$ & $\operatorname{aaa}(\mathrm{K})$ & $\operatorname{gat}(\mathrm{D})$ & $\operatorname{act}(\mathrm{T})$ & $\operatorname{gca}(\mathrm{A})$ & $\operatorname{atc}(\mathrm{I})$ & $\operatorname{gaa}(\mathrm{E})$ \\
2009 H1N1 & $\operatorname{gtc}(\mathrm{V})$ & $\operatorname{gtc}(\mathrm{V})$ & $\operatorname{atg}(\mathrm{M})$ & $\operatorname{aga}(\mathrm{R})$ & $\operatorname{aag}(\mathrm{K})$ & $\operatorname{gaa}(\mathrm{E})$ & $\operatorname{agc}(\mathrm{S})$ & $\operatorname{aca}(\mathrm{T})$ & $\operatorname{gtt}(\mathrm{V})$ & $\operatorname{gat}(\mathrm{D})$ \\
Swine & $\operatorname{ttc}(\mathrm{F})$ & $\operatorname{ttc}(\mathrm{F})$ & $\operatorname{atc}(\mathrm{I})$ & $\operatorname{aga}(\mathrm{R})$ & $\operatorname{aag}(\mathrm{K})$ & $\operatorname{gaa}(\mathrm{E})$ & $\operatorname{act}(\mathrm{T})$ & $\operatorname{act}(\mathrm{T})$ & $\operatorname{att}(\mathrm{I})$ & $\operatorname{gat}(\mathrm{D})$ \\
\hline
\end{tabular}

Table 9. This table contains the consensus nucleotides (codons) at positions in PA that have high importance in separating 2009 pandemic H1N1, avian, and swine from human viruses. The single digit in parenthesis is the position within the codon that was selected by Random Forests. The single letter 'a' (for avian) or 'p' (for pandemic 2009) or 's' (for swine) in parenthesis after a position number indicates whether the position is important for avian or 2009 pandemic H1N1 or swine viruses.

\begin{tabular}{|c|c|c|c|c|c|c|c|}
\hline Position & $55(1)(a)$ & 65(1)(a) & $85(2)(p)$ & $186(1)(\mathrm{p})$ & $225(1)(a, s)$ & $268(1)(\mathrm{s})$ & $272(1)(s)$ \\
\hline Avian & $\operatorname{gat}(\mathrm{D})$ & $\operatorname{tct}(\mathrm{S})$ & $\operatorname{aca}(\mathrm{T})$ & $\operatorname{ggt}(\mathrm{G})$ & $\operatorname{agc}(\mathrm{S})$ & $\operatorname{ctc}(\mathrm{L})$ & $\operatorname{gat}(\mathrm{D})$ \\
\hline Human & $\operatorname{aat}(\mathrm{N})$ & $\operatorname{ctt}(\mathrm{L})$ & $\operatorname{aca}(\mathrm{T})$ & $\operatorname{ggc}(G)$ & $\operatorname{tgc}(C)$ & $\operatorname{atc}(\mathrm{I})$ & $\operatorname{aat}(\mathrm{N})$ \\
\hline 2009 H1N1 & $\operatorname{gac}(\mathrm{D})$ & $\operatorname{tct}(\mathrm{S})$ & $\operatorname{atc}(\mathrm{I})$ & $\operatorname{agt}(\mathrm{S})$ & $\operatorname{agc}(\mathrm{S})$ & $\operatorname{ctc}(\mathrm{L})$ & $\operatorname{gat}(\mathrm{D})$ \\
\hline Swine & $\operatorname{gat}(\mathrm{D})$ & $\operatorname{tct}(\mathrm{S})$ & $\operatorname{aca}(\mathrm{T})$ & $\operatorname{ggt}(\mathrm{G})$ & $\operatorname{agc}(S)$ & $\operatorname{ctc}(\mathrm{L})$ & $\operatorname{gat}(\mathrm{D})$ \\
\hline Position & $275(2)(p)$ & $277(1)(p)$ & $337(1)(a, s)$ & $337(3)(a)$ & $388(3)(\mathrm{p})$ & $421(2)(a, s)$ & $552(2)(\mathrm{a}, \mathrm{s})$ \\
\hline Avian & $\operatorname{cct}(\mathrm{P})$ & $\operatorname{tct}(\mathrm{S})$ & $\operatorname{gct}(\mathrm{A})$ & $\operatorname{gct}(\mathrm{A})$ & $\operatorname{agc}(S)$ & $\operatorname{agt}(\mathrm{S})$ & $\operatorname{act}(\mathrm{T})$ \\
\hline Human & $\operatorname{cct}(\mathrm{P})$ & $\operatorname{tat}(\mathrm{Y})$ & $\operatorname{tca}(\mathrm{S})$ & $\operatorname{tca}(\mathrm{S})$ & $\operatorname{agc}(S)$ & atc(I) & $\operatorname{agt}(\mathrm{S})$ \\
\hline 2009 H1N1 & $\operatorname{ctt}(\mathrm{L})$ & $\operatorname{cat}(\mathrm{H})$ & $\operatorname{gct}(\mathrm{A})$ & $\operatorname{gct}(\mathrm{A})$ & $\operatorname{gga}(G)$ & $\operatorname{agc}(\mathrm{S})$ & $\operatorname{act}(\mathrm{T})$ \\
\hline Swine & $\operatorname{ccc}(\mathrm{P})$ & $\operatorname{tct}(\mathrm{S})$ & $\operatorname{gct}(\mathrm{A})$ & $\operatorname{gct}(\mathrm{A})$ & $\operatorname{agt}(\mathrm{S})$ & $\operatorname{agc}(\mathrm{S})$ & $\operatorname{act}(\mathrm{T})$ \\
\hline
\end{tabular}

PB1 contains several functional domains, including cRNA binding domain (codons 1-139 and 267-493), vRNA binding domain (codons 1-83 and 233-249 and 494-758), NLS region (codons 180-195 and 202-252), PA binding domain (codons 1-25), and PB2 binding domain (codons 600-757) [5].

In comparison of human with avian, 2009 pandemic H1N1, and swine viruses, there were several synonymous mutation positions in PB1 with high importance. They were 148(3) (gag(E), gaa(E)), 322(3) (ata(I), att(I)), and 454(3) $(\operatorname{ccg}(\mathrm{P}), \operatorname{cca}(\mathrm{P}))$ in avian, 62(3) $(\operatorname{ggt}(\mathrm{G})$, $\operatorname{ggg}(\mathrm{G})), 167(1)(\operatorname{tta}(\mathrm{L}), \operatorname{ctc}(\mathrm{L})), 543(3)(\operatorname{acg}(\mathrm{T}), \operatorname{aca}(\mathrm{T}))$, and 601(3) (ata(I), atc(I)) in 2009 pandemic H1N1, 60(3) $(\operatorname{gag}(\mathrm{E}), \operatorname{gaa}(\mathrm{E}))$ and $726(3)(\mathrm{gca}(\mathrm{A}), \operatorname{gcc}(\mathrm{A}))$ in swine (Figure 9). It was striking that codons 322(3), 167(1), and $60(3)$, each carrying a synonymous mutation, had the highest importance in 2009 pandemic H1N1, avian, and swine, respectively. Many of these significant codons carrying synonymous mutations were located in the functional domains of PB1. 

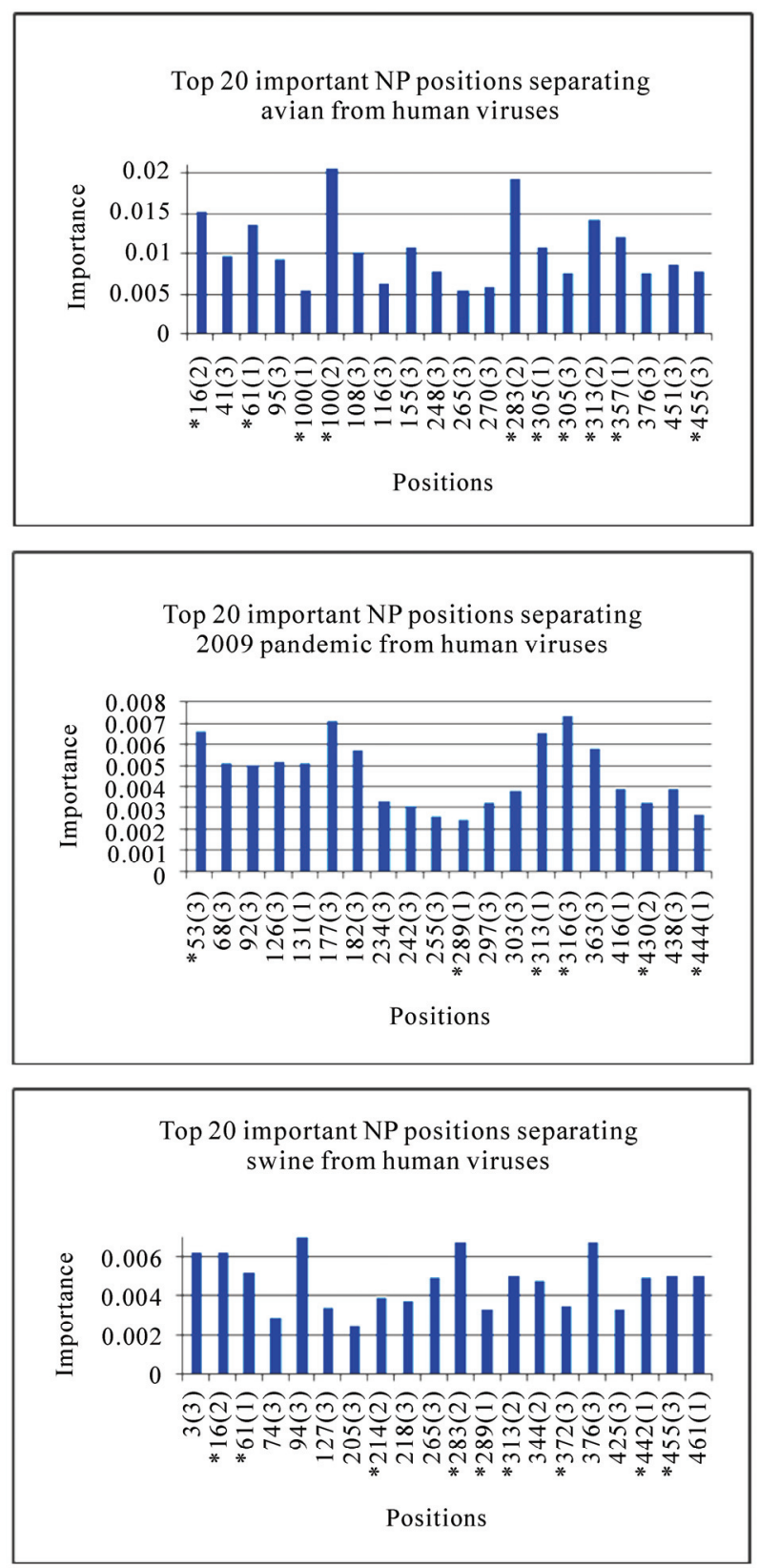

Figure 7. Top important NP codon positions in distinguishing avian, human, 2009 pandemic H1N1, and swine viruses. The single digit in parenthesis is the position within the codon that was selected by Random Forests. The positions with an asterisk are the important residue positions identified in [8].

\subsubsection{PB2 Gene}

Amino acid positions 9, 44, 64, 81, 105, 199, 271, 292, $368,475,567,588,613,627,661,674$, and 702 were avian-human host shift markers in [4]. Codons 81(2), 105(2), 199(1), 271(1), 475(1), 588(2), 627(1), 674(1), and 674(3) were significant avian-human markers in this study and in [8]. In particular, our analysis revealed
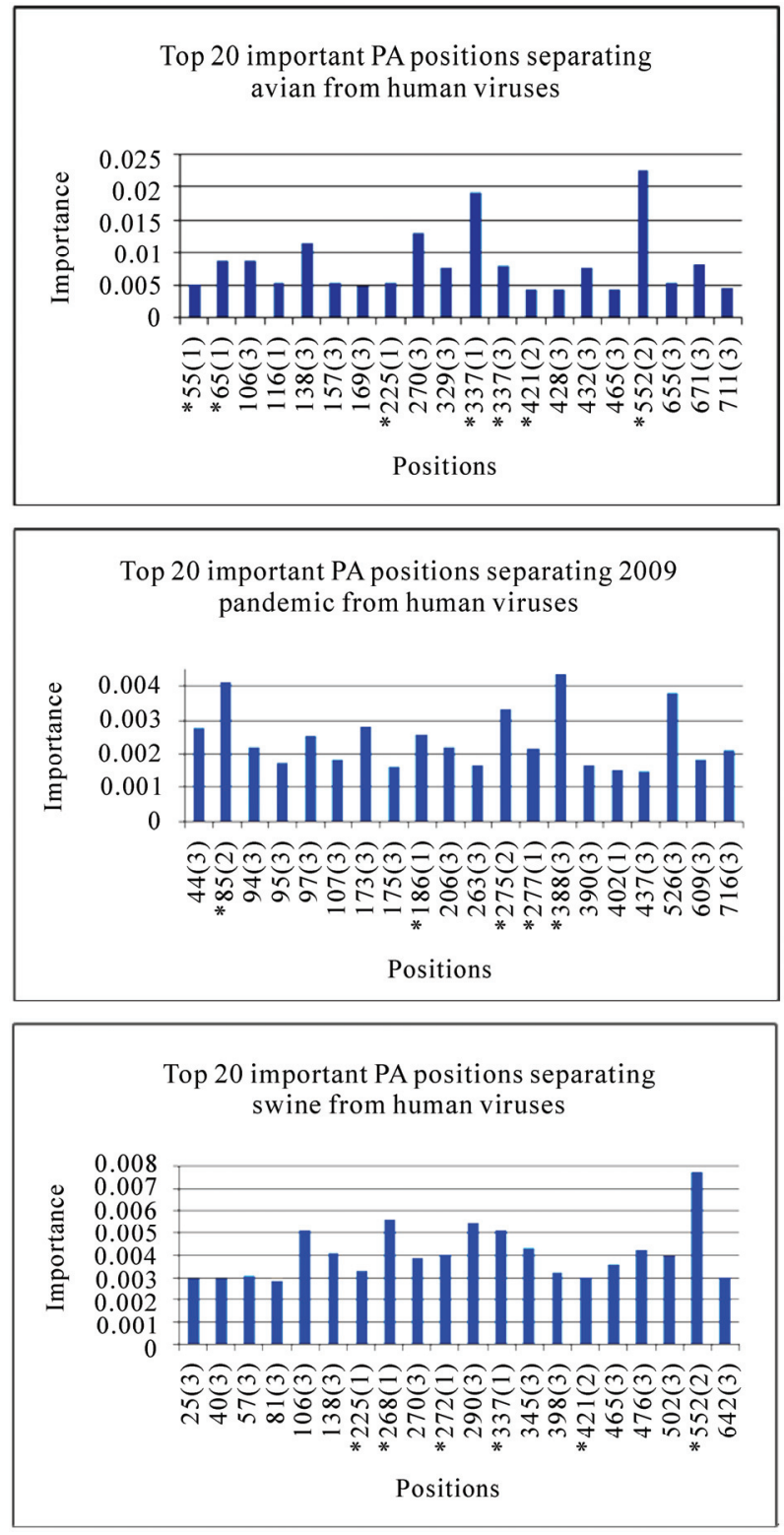

Figure 8. Top important PA codon positions in distinguishing avian, human, 2009 pandemic H1N1, and swine viruses. The single digit in parenthesis is the position within the codon that was selected by Random Forests. The positions with an asterisk are the important residue positions identified in [8].

codon 199(1) as equally essential as codon 627(1), a well-known host marker (Figure 10).

Residue position 44 was a swine-human marker in [32]. Our analysis and [8] implied codons 81(2), 199(1), $567(1), 613(1)$, and 674(1) were as equally significant as position 44. In fact, codon 674(1) received the highest importance in swine. Moreover, codons 54(2), 225(1), 315(3), 559(2), 591(2), and 645(1) were key host markers in 2009 pandemic H1N1. 

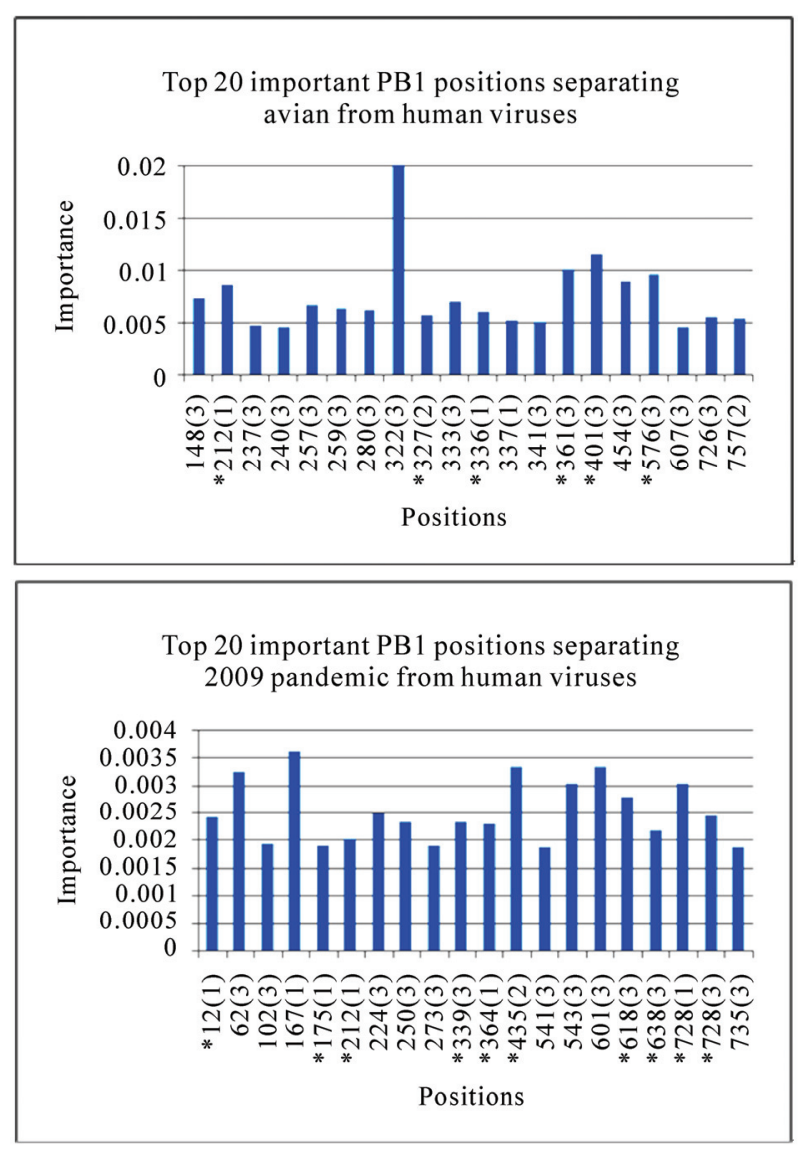

Top 20 important $\mathrm{PB} 1$ positions separating swine from human viruses

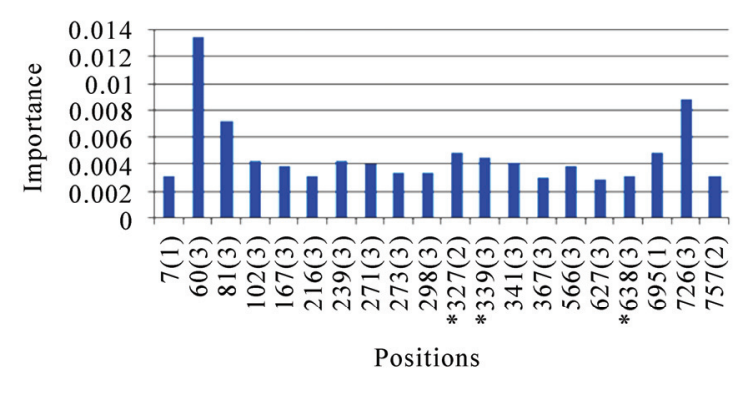

Figure 9. Top important PB1 codon positions in distinguishing avian, human, 2009 pandemic H1N1, and swine viruses. The single digit in parenthesis is the position within the codon that was selected by Random Forests. The positions with an asterisk are the important residue positions identified in [8].

In comparison of human with avian, 2009 pandemic H1N1, and swine viruses, there were several synonymous mutation positions in PB2 with high importance. They were 373(3) (att(I), ata(I)), 598(3) (aca(T), act(T)), and 604(3) $(\operatorname{cgt}(\mathrm{R})$, aga(R)) in avian, 142(1) $(\operatorname{agg}(\mathrm{R})$, $\operatorname{cgc}(\mathrm{R})), 142(3)(\operatorname{agg}(\mathrm{R}), \operatorname{cgc}(\mathrm{R})), 221(3)(\operatorname{gcc}(\mathrm{A}), \operatorname{gct}(\mathrm{A}))$, $553(3)(\operatorname{ata}(\mathrm{I})$, atc(I)), and 664(1) (cga(R), aga(R)) in 2009 pandemic H1N1, and 169(3) (cca(P), ccc(P)) and 527(1) $(\operatorname{ttg}(\mathrm{L}), \operatorname{ctg}(\mathrm{L}))$ in swine (Figure 10). There was one codon 142 carrying two synonymous mutation positions, both were selected as important host markers in 2009 pandemic H1N1. Codons 221(3), 553(3), and 664(1) were the top three important ones in 2009 pandemic H1N1. The PB2-NP binding domain contains codons 1-269 and 580-683, and the PB2-PB1 binding domain contains codons 51-259 and 580-759 [5]. Codons 142(1), 142(3), 169(3), 221(3), 598(3), 604(3), and 664(1) were in the PB2-PB1 and PB2-NP binding domains.

In addition to codon 142 in 2009 pandemic H1N1, there was one codon 674 in avian (Figure 10) that included two significant positions. The likelihood to affect the host shifts by any potential mutations at these multiple selected codons might be higher than any other codons.

\section{DISCUSSION}

In the current study, a comprehensive analysis of the nucleotide sequences of ten genes of influenza viruses was performed to discover a catalogue of host markers, illustrating the complex and systematic nature of host adaptation. One of the benefits of using nucleotide sequences was their capability to detect synonymous mutations that were essential for host switches. These synonymous mutations could not be found at the amino acid level. Moreover, the nucleotide markers could pinpoint exactly where the important positions were within a codon.

Our investigation also revealed several codons in ten genes of 2009 pandemic H1N1, avian, and swine viruses that contained two or even three important positions selected by Random Forests for host shifts, thus providing extra and finer information about the host adaptation. These codons might have a higher probability to affect the host switch than those codons containing only a single important position.

Amino acid mutation E627K in PB2 is a well-known determinant for adaptation from avian to human hosts. The nucleotide marker information uncovered in this study suggested that generally it was codon gaa to encode $\mathrm{E}$ in avian viruses and codon aag to encode $\mathrm{K}$ in human viruses. Furthermore, it was the first position within codon 627 that was essential for the discrimination of avian and human viruses, although there was another possibility in the third position within codon 627 . The SR polymorphism found in [10] contained two positions 590 and 591. Our analysis demonstrated that it was the second position within codon 591 that was really vital for the separation of 2009 pandemic H1N1 and human viruses (Table 11). 
Table 10. This table contains the consensus nucleotides (codons) at positions in PB1 that have high importance in separating 2009 pandemic H1N1, avian, and swine from human viruses. The single digit in parenthesis is the position within the codon that was selected by Random Forests. The single letter 'a' (for avian) or 'p' (for pandemic 2009) or 's' (for swine) in parenthesis after a position number indicates whether the position is important for avian or 2009 pandemic H1N1 or swine viruses.

\begin{tabular}{|c|c|c|c|c|c|c|c|c|}
\hline Position & $12(1)(p)$ & $175(1)(\mathrm{p})$ & $212(1)(a, p)$ & $327(2)(a, s)$ & $336(1)(a)$ & $339(3)(\mathrm{p}, \mathrm{s})$ & $361(3)(a)$ & $364(1)(p)$ \\
\hline Avian & $\operatorname{gtt}(\mathrm{V})$ & $\operatorname{gat}(\mathrm{D})$ & $\operatorname{ctg}(\mathrm{L})$ & aga(R) & $\operatorname{gtc}(V)$ & $\operatorname{att}(\mathrm{I})$ & $\operatorname{agc}(S)$ & $\operatorname{ctt}(\mathrm{L})$ \\
\hline Human & $\operatorname{gtt}(\mathrm{V})$ & $\operatorname{gat}(\mathrm{D})$ & $\operatorname{gtg}(\mathrm{V})$ & aaa $(\mathrm{K})$ & $\operatorname{atc}(\mathrm{I})$ & $\operatorname{atc}(\mathrm{I})$ & aga(R) & $\operatorname{ctc}(\mathrm{L})$ \\
\hline 2009 H1N1 & $\operatorname{att}(\mathrm{I})$ & $\operatorname{aac}(\mathrm{N})$ & $\operatorname{ctg}(\mathrm{L})$ & aga(R) & $\operatorname{atc}(\mathrm{I})$ & $\operatorname{atg}(\mathrm{M})$ & aga(R) & $\operatorname{att}(\mathrm{I})$ \\
\hline Swine & $\operatorname{gtg}(V)$ & $\operatorname{gat}(\mathrm{D})$ & $\operatorname{ttg}(\mathrm{L})$ & $\operatorname{aga}(\mathrm{R})$ & $\operatorname{gtt}(V)$ & $\operatorname{att}(\mathrm{I})$ & $\operatorname{agc}(\mathrm{S})$ & $\operatorname{ctc}(\mathrm{L})$ \\
\hline Position & 401(3)(a) & $435(2)(\mathrm{p})$ & $576(3)(a)$ & $618(3)(\mathrm{p})$ & $638(3)(\mathrm{p}, \mathrm{s})$ & $728(1)(p)$ & $728(3)(\mathrm{p})$ & \\
\hline Avian & $\operatorname{gcc}(\mathrm{A})$ & $\mathrm{aca}(\mathrm{T})$ & $\operatorname{ctg}(\mathrm{L})$ & gaa(E) & $\operatorname{gag}(\mathrm{E})$ & att(I) & $\operatorname{att}(\mathrm{I})$ & \\
\hline Human & $\operatorname{gca}(\mathrm{A})$ & $\operatorname{aca}(\mathrm{T})$ & $\operatorname{cta}(\mathrm{L})$ & $\operatorname{gag}(\mathrm{E})$ & $\operatorname{gag}(\mathrm{E})$ & att(I) & att(I) & \\
\hline 2009 H1N1 & $\operatorname{gca}(\mathrm{A})$ & $\operatorname{ata}(\mathrm{I})$ & $\operatorname{tta}(\mathrm{L})$ & $\operatorname{gat}(\mathrm{D})$ & $\operatorname{gat}(\mathrm{D})$ & $\operatorname{gtc}(V)$ & $\operatorname{gtc}(V)$ & \\
\hline Swine & gca(A) & $\mathrm{aca}(\mathrm{T})$ & $\operatorname{cta}(\mathrm{L})$ & gaa(E) & gaa(E) & $\operatorname{att}(\mathrm{I})$ & $\operatorname{att}(\mathrm{I})$ & \\
\hline
\end{tabular}

Table 11. This table contains the consensus nucleotides (codons) at positions in M1 that have high importance in separating 2009 pandemic H1N1, avian, and swine from human viruses. The single digit in parenthesis is the position within the codon that was selected by Random Forests. The single letter 'a' (for avian) or 'p' (for pandemic 2009) or 's' (for swine) in parenthesis after a position number indicates whether the position is important for avian or 2009 pandemic H1N1 or swine viruses.

\begin{tabular}{|c|c|c|c|c|c|c|c|c|c|}
\hline Position & $44(1)(s)$ & $54(2)(\mathrm{p})$ & $81(2)(a, s)$ & $105(2)(a)$ & $199(1)(a, s)$ & $225(1)(p)$ & 271(1)(a) & $315(3)(\mathrm{p})$ & $475(1)(a)$ \\
\hline Avian & $\operatorname{gca}(\mathrm{A})$ & aаa $(\mathrm{K})$ & $\operatorname{aca}(\mathrm{T})$ & $\operatorname{aca}(\mathrm{T})$ & $\operatorname{gct}(\mathrm{A})$ & $\operatorname{agc}(S)$ & $\operatorname{aca}(\mathrm{T})$ & $\operatorname{atg}(\mathrm{M})$ & $\operatorname{ctg}(\mathrm{L})$ \\
\hline Human & $\operatorname{tca}(\mathrm{S})$ & aaa $(\mathrm{K})$ & $\operatorname{atg}(\mathrm{M})$ & $\operatorname{gtg}(V)$ & $\operatorname{tct}(\mathrm{S})$ & $\operatorname{agc}(\mathrm{S})$ & $\operatorname{gca}(\mathrm{A})$ & $\operatorname{atg}(\mathrm{M})$ & $\operatorname{atg}(\mathrm{M})$ \\
\hline 2009 H1N1 & $\operatorname{gca}(\mathrm{A})$ & $\operatorname{aga}(\mathrm{R})$ & $\operatorname{aca}(\mathrm{T})$ & $\operatorname{aca}(\mathrm{T})$ & $\operatorname{gct}(\mathrm{A})$ & $\operatorname{ggc}(\mathrm{G})$ & $\operatorname{gca}(\mathrm{A})$ & $\operatorname{ata}(\mathrm{I})$ & $\operatorname{ctg}(\mathrm{L})$ \\
\hline Swine & $\operatorname{gca}(\mathrm{A})$ & aаa $(\mathrm{K})$ & $\mathrm{aca}(\mathrm{T})$ & $\operatorname{aca}(\mathrm{T})$ & $\operatorname{gct}(\mathrm{A})$ & $\operatorname{agc}(S)$ & $\operatorname{aca}(\mathrm{T})$ & $\operatorname{atg}(\mathrm{M})$ & $\operatorname{ctg}(\mathrm{L})$ \\
\hline Position & $559(2)(\mathrm{p})$ & $567(1)(\mathrm{s})$ & $588(2)(\mathrm{a})$ & $591(2)(\mathrm{p})$ & $613(1)(\mathrm{s})$ & $627(1)(a)$ & $645(1)(p)$ & $674(1)(a, s)$ & $674(3)(a)$ \\
\hline Avian & $\operatorname{act}(\mathrm{T})$ & $\operatorname{gac}(\mathrm{D})$ & $\operatorname{gcc}(\mathrm{A})$ & caa(Q) & $\operatorname{gtt}(\mathrm{V})$ & gaa(E) & $\operatorname{atg}(\mathrm{M})$ & $\operatorname{gca}(\mathrm{A})$ & $\operatorname{gca}(\mathrm{A})$ \\
\hline Human & $\operatorname{gct}(\mathrm{A})$ & $\operatorname{aat}(\mathrm{N})$ & $\operatorname{att}(\mathrm{I})$ & caa $(Q)$ & $\operatorname{acc}(\mathrm{T})$ & $\operatorname{aag}(\mathrm{K})$ & $\operatorname{atg}(\mathrm{M})$ & $\operatorname{act}(\mathrm{T})$ & $\operatorname{act}(\mathrm{T})$ \\
\hline 2009 H1N1 & $\operatorname{att}(\mathrm{I})$ & $\operatorname{gat}(\mathrm{D})$ & $\operatorname{acc}(\mathrm{T})$ & $\operatorname{cgg}(\mathrm{R})$ & $\operatorname{gtc}(V)$ & gaa(E) & $\operatorname{ttg}(\mathrm{L})$ & $\operatorname{gca}(\mathrm{A})$ & $\operatorname{gca}(\mathrm{A})$ \\
\hline Swine & $\operatorname{act}(\mathrm{T})$ & $\operatorname{gac}(\mathrm{D})$ & $\operatorname{gcc}(\mathrm{A})$ & caa(Q) & $\operatorname{gtc}(V)$ & gaa(E) & $\operatorname{atg}(\mathrm{M})$ & $\operatorname{gca}(\mathrm{A})$ & $\operatorname{gca}(\mathrm{A})$ \\
\hline
\end{tabular}

In [8], a set of residue positions in the PB2 protein including the SR polymorphism found in [10] were identified as host markers in 2009 pandemic H1N1. Codons 54(2), 225(1), 315(3), 559(2), 591(2), and 645(1) in PB2 of 2009 pandemic H1N1 were concluded as essential host markers both in this study and in [8]. Furthermore, the current study found three new codons 221(3), 553(3), and 664(1) that were the top three significant codons in 2009 pandemic H1N1. They could augment the repertoire of existing host markers in PB2 that might play com- pensatory roles, as the SR polymorphism, in the viral replication and transmission of 2009 pandemic H1N1. Additionally, the new nucleotide markers carrying synonymous mutations found in NP, PA, and PB1, along with those in PB2 would provide further information for the life cycle of 2009 pandemic H1N1. Also, codons 728(1), 728 (3) in PB1, carrying a non-synonymous mutation, and codons 142(1), 142(3) in PB2, carrying a synonymous mutation, were of special interest in this regard as multiple selected markers within the same codon. 

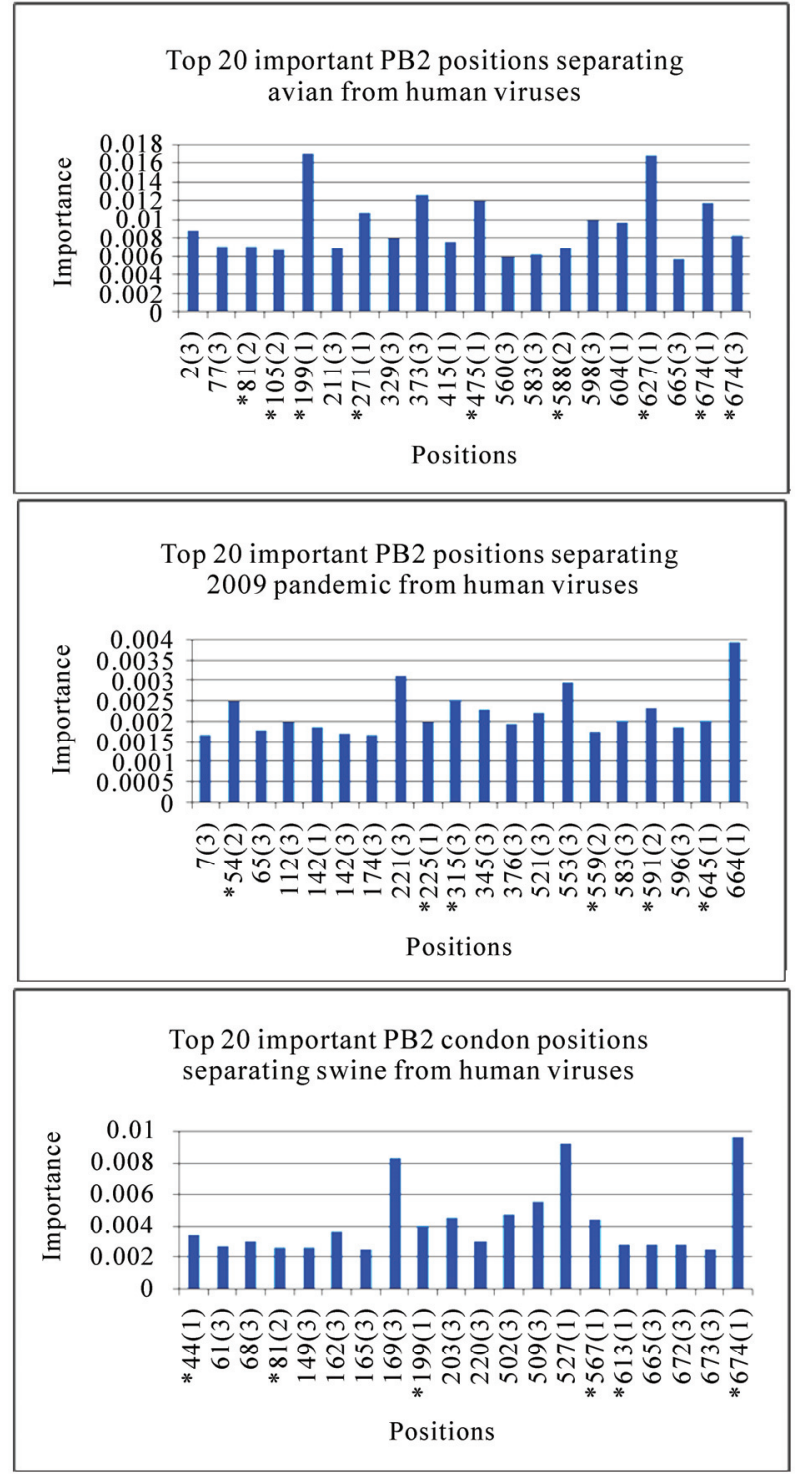

Figure 10. Top important PB2 codon positions in distinguishing avian, human, 2009 pandemic H1N1, and swine viruses. The single digit in parenthesis is the position within the codon that was selected by Random Forests. The positions with an asterisk are the important residue positions identified in [8].

\section{CONCLUSION}

As an extension of our earlier work in [8], Random Forests were employed to discover a collection of nucleotide positions, served as host markers, in ten genes of influenza that could separate 2009 pandemic H1N1, avian, and swine viruses from human viruses with high confidence. Our results indicated that two or even three important positions could coexist within a single codon, i.e., multiple nucleotide markers might be present within one codon, and the different importance values of these positions could further differentiate these multiple mar- kers within a codon. The nucleotide markers uncovered in the current study provided a complete genomic view of host adaptation of influenza viruses. They verified and enriched the known amino acid host markers and generated new information about the adaptation of zoonotic viruses to humans, thus offering a larger set of finer potential sites for further experimental verification to elucidate their biological functions in cellular processes.

\section{ACKNOWLEDGEMENTS}

We thank Houghton College for its financial support.

\section{REFERENCES}

[1] Chen, G.W., Chang, S.C., Mok, C.K., Lo, Y.L., Kung, Y.N., et al. (2006) Genomic signatures of human versus avian influenza A viruses. Emerging Infectious Diseases, 12(9), 1353-1360.

[2] Chen, G.W. and Shih, S.R. (2009) Genomic signatures of influenza A pandemic (H1N1) 2009. Emerging Infectious Diseases, 15(12), 1897-1903.

[3] Pan, C., Cheung, B., Tan, S., Li, C., Li, L., et al. (2010) Genomic signature and mutation trend analysis of pandemic (H1N1) 2009. Influenza A Virusus PLoS One, 5(3), e9549.

[4] Miotto, O., Heiny, A., Tan, T.W., August, J.T. and Brusic, V. (2008) Identification of human-to-human transmissibility factors in PB2 proteins of influenza A by largescale mutual information analysis. BMC Bioinformatics. 9(Suppl 1), S18.

[5] Miotto, O., Heiny, A.T., Albrecht, R., García-Sastre, A., Tan, T.W., August, J.T. and Brusic, V. (2010) Complete-proteome mapping of human influenza A adaptive mutations: Implications for human transmissibility of zoonotic strains. PLoS One, 5(2), e9025.

[6] Finkelstein, D.B., Mukatira, S., Mehta, P.K., Obenauer, J.C., Su, X., Webster, R.G. and Naeve, C.W. (2007) Persistent host markers in pandemic and $\mathrm{H} 5 \mathrm{~N} 1$ influenza viruses. Journal of Virology, 81(19), 10292-10299.

[7] Allen, J.E., Gardner, S.N., Vitalis, E.A. and Slezak, T.R. (2009) Conserved amino acid markers from past influenza pandemic strains. BMC Microbiology, 9(1), 77.

[8] Hu, W. (2010) Novel host markers in the 2009 pandemic H1N1 influenza A virus. Journal of Biomedical Science and Engineering, 3(6), 584-601.

[9] Herfst, S., Chutinimitkul, S., Ye, J., de Wit, E., Munster, V.J., Schrauwen, E.J., Bestebroer, T.M., Jonges, M., Meijer, A., Koopmans, M., Rimmelzwaan, G.F., Osterhaus, A.D., Perez, D.R. and Fouchier, R.A. (2010) Introduction of virulence markers in $\mathrm{PB} 2$ of pandemic swine-origin influenza virus does not result in enhanced virulence or transmission, Journal of Virology, 84(8), 3752-3758.

[10] Mehle, A. and Doudna, J.A. (2009) Adaptive strategies of the influenza virus polymerase for replication in humans. Proceedings of National Academic Science in USA., 106(50), 21312-21316.

[11] Alexande,r S., Benjamin, G., Gustavo, P., Ian Lipkin, W. and Raul R. (2010) Host dependent evolutionary patterns 
and the origin of $2009 \mathrm{H} 1 \mathrm{~N} 1$ pandemic influenza. PLoS Current Influenza, RRN1147.

[12] Rabadan, R., Levine, A.J. and Robins, H. (2006) Comparison of avian and human influenza A viruses reveals a mutational bias on the viral genomes. Journal of Virology, 80(23), 11887-11891.

[13] Microbiol Biotechnol, J. (2010) Comparative study of the nucleotide bias between the novel H1N1 and H5N1 subtypes of influenza A viruses using bioinformatics techniques. Ahn I, Son HS. Bioinformatics Team, 20(1), 6370.

[14] Valli, M.B., Meschi, S., Selleri, M., Zaccaro, P., Ippolito, G., Capobianchi, M.R. and Menzo, S. (2010) Evolutionary pattern of pandemic influenza (H1N1) 2009 virus in the late phases of the 2009 pandemic. PLoS Current Influenza, RRN1149.

[15] Ramakrishnan, M.A., Gramer, M.R., Goyal, S.M. and Sreevatsan, S. (2009) A Serine12Stop mutation in PB1F2 of the 2009 pandemic (H1N1) influenza A: a possible reason for its enhanced transmission and pathogenicity to humans. Journal of Veterinary Science, 10(4), 349-351.

[16] Katoh, K., Kuma, K., Toh, H. and Miyata, T. (2005) MAFFT version 5: improvement in accuracy of multiple sequence alignment. Nucleic Acid Research, 33, 511-518.

[17] Breiman, L. (2001) Random Forests, Machine Learning, 45(1), 5-32.

[18] Díaz-Uriarte, R. and Alvarez de Andrés, S. (2006) Gene selection and classification of microarray data using random forest. BMC Bioinformatics, 7(3), 3-16.

[19] Archer, K.J. and Kimes, R.V. (2008) Empirical characterization of random forest variable importance measures. Computational Statistics and Data Analysis, 52(4), 22492260.

[20] Reif, D.M., Motsinger, A.A., McKinney, B.A., Crowe, J.E. and Moore, J.H. (2006) Feature selection using a random forests classifier for the integrated analysis of multiple data types. Proceedings of 2006 IEEE Symposium on Computational Intelligence and Bioinformatics and Computational Biology, CIBCB '06.

[21] Granittoa, P.M., Furlanellob, C., Biasiolia, F. and Gasperia, F. (2006) Recursive feature elimination with random forest for PTR-MS analysis of agroindustrial products. Chemometrics and Intelligent Laboratory Systems, 83(2), 83-90.

[22] Menze1, B.H., Kelm, B.M., Masuch, R., Himmelreich, U., Bachert, P., Petrich, W. and Hamprecht, F.A. (2009) A comparison of random forest and its Gini importance with standard chemometric methods for the feature selection and classification of spectral data. BMC Bioinformatics, 10, 213.

[23] Gao, D., Zhang, Y.-X. and Zhao, Y.-H. (2009) Random forest algorithm for classification of multi-wavelength data. Research in Astronomy and Astrophysics, 9(2), 220 226.

[24] Hu, W. (2009) Identifying predictive markers of chemosensitivity of breast cancer with random forests. Journal of Biomedical Science and Engineering, 3(1), 59-64.

[25] Gavin, J.D., Smith, D.V., Justin, B., Samantha, J.L., et al. (2009) Origins and evolutionary genomics of the 2009 swine-origin H1N1 influenza A epidemic. Nature, 459(7250), 1122-1125.

[26] Hu, W. (2010) Quantifying the effects of mutations on receptor binding specificity of influenza viruses. Journal of Biomedical Science and Engineering, 3(3), 227-240.

[27] KováccaronOVá, A., Ruttkay-Nedecký, G., HaverlíK1, I.K. and Janecccaronek, S. (2002) Sequence similarities and evolutionary relationships of influenza virus A hemagglutinins. Virus Genes, 24(1), 57-63.

[28] Colman, P.M., Hoyne, P.A. and Lawrence, M.C. (1993) Sequence and structure alignment of paramyxovirus hemagglutinin-neuraminidase with influenza virus neuraminidase. Journal of Virology, 67(6), 2972-2980.

[29] Maurer-Stroh, S., Ma, J.M., Lee, R.T.C., Sirota, F.L. and Eisenhaber, F. (2009) Mapping the sequence mutations of the $2009 \mathrm{H} 1 \mathrm{~N} 1$ influenza A virus neuraminidase relative to drug and antibody binding sites. Biology Direct, 4, 18 .

[30] Baudin, F., Petit, I., Weissenhorn, W. and Ruigrok, R.W.H. (2001) In vitro dissection of the membrane binding and RNP binding activities of influenza virus M1 protein. Virology, 281(1), 102-108.

[31] Furuse, Y., Suzuki, A., Kamigaki, T. and Oshitani, H. (2009) Evolution of the M gene of the influenza A virus in different host species: Large-scale sequence analysis. Journal of Virology, 6(1), 67.

[32] Yang, H., Carney, P. and Stevens, J. (2010) Structure and Receptor binding properties of a pandemic H1N1 virus hemagglutinin. PLoS Current Influenza, RRN1152.

[33] Dundon, W.G. and Capua, I. (2009) A closer look at the NS1 of influenza virus. Viruses, 1(3), 1057-1072.

[34] Lin, D., Lan, J. and Zhang, Z. (2007) Structure and function of the NS1 protein of influenza A virus. Acta Biochim Biophys Sin (Shanghai), 39(3), 155-162.

[35] Ye, Q., Krug, R.M. and Tao, Y.J. (2006) The mechanism by which influenza A virus nucleoprotein forms oligomers and binds RNA. Nature, 444(7122), 1078-1082.

[36] Liu, X. and Zhao, Y.P. (2010) Switch region for pathogenic structural change in conformational disease and its prediction. PLoS One, 5(1), e8441.

[37] Yuan, P.W., Bartlam, M., Lou, Z.Y., Chen, S.D., Zhou, J., He, X.J., Lv, Z.Y., Ge, R.W., Li, X.M., Deng, T., Fodor, E., Rao, Z.H. and Liu, Y.F. (2009) Crystal structure of an avian influenza polymerase PAN reveals an endonuclease active site. Nature, 458(7240), 909-913. 